\section{OAK RIDGE NATIONAL LABORATORY}

CONFIRMATORY RADIOLOGICAL SURVEY OF THE BORAX-V TURBINE BUILDING IDAHO NATIONAL ENGINEERING LABORATORY

IDAHO FALLS, IDAHO

\author{
G. H. Stevens \\ R. L. Coleman \\ M. K. Jensen \\ G. A. Picrce \\ P. V. Egidi \\ S. K. Mather
}


This report has been reproduced directly from the best available copy.

Available to DOE and DOE contractors from the Otfice of Scientific and Techni cal Information, P.O. Box 62, Oak Pidge, TN 37831; prices available from (615) 576.8401, FTS 626-8401.

Available to the public from the National Technical Information Service, U.S. Department of Commerce. 5285 Port Royal Rd., Springfield, VA 22161.

This report was prepared as an account of work sponsored by an agency of the United States Government. Neither the United States Government nor any agency thereof, nor any of their employees, makes any warranty, express or implied, or assumes any legal liability or responsibility for the accuracy, completeness, or usefuiness of any information, apparatus, product, or process disclosed, or represents that its use would not infringe privately owned rights. Reference herein to any specific commercial product, process, or service by trade name, trademark, manufacturer, or otherwise, does not necessarily constitute or imply its endersement, recommendation, or favoring by the United States Government or any agency thereof. The views and opinions of authors expressed herein do not necessarily state or reflect those of the United States Government or any agency thereof. 


\title{
CONFIRMATORY RADIOLOGICAL SURVEY OF THE BORAX-V TURBINE BUILDING IDAHO NATIONAL ENGINEERING LABORATORY IDAHO FALIS, IDAHO
}

\author{
G. H. Stevens \\ R. L Coleman \\ M. K. Jensen \\ G. A. Pierce \\ P. V. Egidi* \\ S. K. Mather*
}

*Oak Ridge Institute for Science and Education

Date Published -

Prepared for the

Decontamination and Decommissioning Branch

U.S. Department of Energy

Prepared by

OAK RIDGE NATIONAL LABORATORY

Oak Ridge, Tennessee 37831-6036

managed by

MARTIN MARIETTA ENERGY SYSTEMS, INC.

for the

U.S. DEPARTMENT OF ENERGY

under contract DE-ACO5-84OR21400

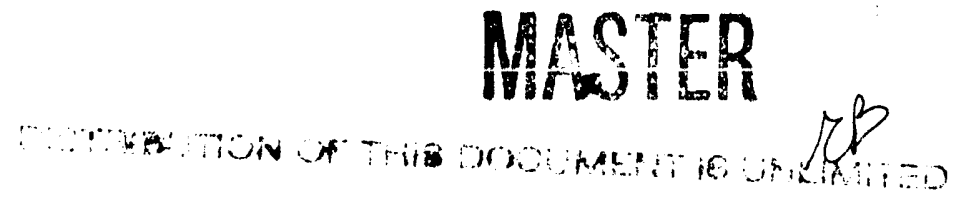


CONTENTS

FIGURES $\ldots \ldots \ldots \ldots \ldots \ldots \ldots \ldots \ldots \ldots \ldots \ldots \ldots$

TABLES $\ldots \ldots \ldots \ldots \ldots \ldots \ldots \ldots \ldots \ldots \ldots \ldots \ldots \ldots$ vi

ACKNOWLEDGEMENTS $\ldots \ldots \ldots \ldots \ldots \ldots \ldots \ldots \ldots$ ix

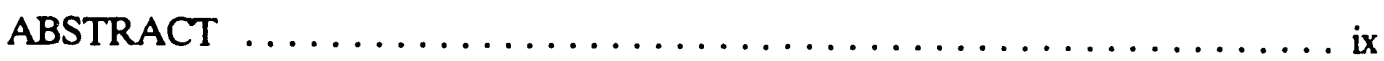

1. INTRODUCTION $\ldots \ldots \ldots \ldots \ldots \ldots \ldots \ldots \ldots \ldots \ldots \ldots$

1.1 TASK DESCRIPTION $\ldots \ldots \ldots \ldots \ldots \ldots \ldots \ldots \ldots \ldots$

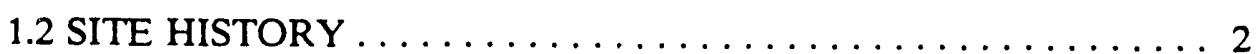

2. INDEPENDENT VERIFICATION PROCESS $\ldots \ldots \ldots \ldots \ldots \ldots \ldots \ldots 4$

2.1 DOCUMENT REVIEW $\ldots \ldots \ldots \ldots \ldots \ldots \ldots \ldots \ldots$

2.2 FIELD SURVEY $\ldots \ldots \ldots \ldots \ldots \ldots \ldots \ldots \ldots \ldots \ldots \ldots$

2.2.1 Background Radiation Investigation $\ldots \ldots \ldots \ldots \ldots$

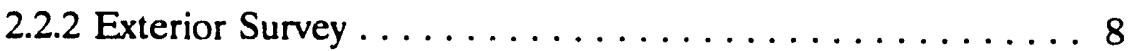

2.2.3 Interior Survey $\ldots \ldots \ldots \ldots \ldots \ldots \ldots \ldots \ldots \ldots$

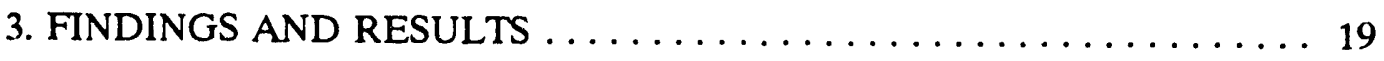

3.1 DOCUMENT REVIEW $\ldots \ldots \ldots \ldots \ldots \ldots \ldots \ldots \ldots$

3.2 BACKGROUND RADIATION MEASUREMENTS . . . . . . . . 19

3.3 EXTERIOR RADIATION MEASUREMENTS . . . . . . 20

3.4 TURBINE BUIL.DING RADIATION MEASUREMENTS . . . . 20

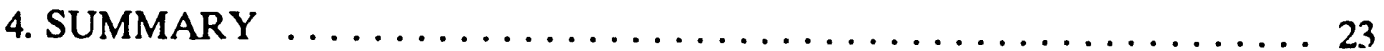

REFERENCES ......................... 28

ACRONYMS, INITIALISMS, AND ABBREVIATIONS .......... 29

APPENDIX A POST-REMEDIATION SURVEY BY EG\&G

APPENDIX B SURVEY AND ANALYTICAL EQUIPMENT

APPENDIX C DECONTAMINATION OF HOT SPOTS IDENTIFIED

AT BORAX-V

APPENDIX D STATEMENT OF VERIFICATION 


\section{FIGURES}

1 INEL, showing location of BORAX-V site $\ldots \ldots \ldots \ldots \ldots \ldots$

2 Sampling locations for background concentrations $\ldots \ldots \ldots \ldots \ldots$

3 Turbine building interior walls and floor, showing PIC and additional fixedpoint measurement locations $\ldots \ldots \ldots \ldots \ldots \ldots \ldots \ldots \ldots \ldots \ldots \ldots$

4 Exterior grid, showing sampling locations and elevated gamma radiation

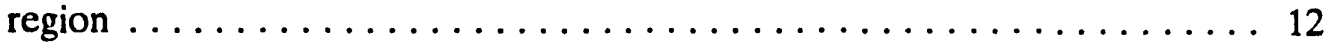

5 Exterior wall grids, side view $\ldots \ldots \ldots \ldots \ldots \ldots \ldots \ldots \ldots \ldots \ldots \ldots$

6 Turbine building mezzanine grid, showing PIC measurement

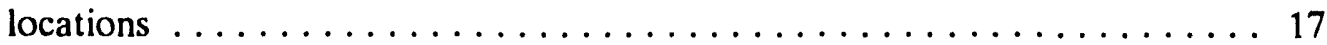

7 Turbine building floor, showing elevated beta-gamma radiation regions $\ldots .25$ 


\section{TABLES}

1 Surface Contamination Guidelines, DOE Order $5400.5 \ldots \ldots \ldots \ldots$

2 Background exposure rates and soil concentrations . . . . . . . . . . 10

3 Summary of BORAX-V turbine building surface-activity results . . . . . 15

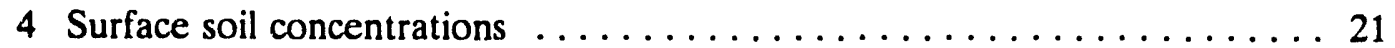

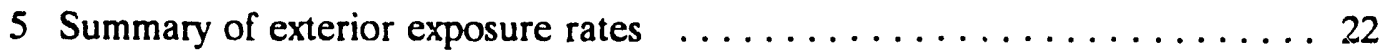

6 Summary of interior removable contamination $\ldots \ldots \ldots \ldots \ldots \ldots$

7 Location of elevated direct radiation identified by scans of the BORAX-V turbine building basement floor and trench $\ldots \ldots \ldots \ldots \ldots$ 


\section{ACKNOWLEDGEMENTS}

This project was sponsored by the U.S. Department of Energy (DOE), under contract DE-AC05-84OR21400 with Martin Marietta Energy Systems, Inc. The authors wish to acknowledge W.D. Cottrell of the ORNL/OR office for providing valuable technical support for planning, field surveys, and assistance in interpretation and review. The following ORNL/GJ office staff are gratefully acknowledged: D.K. Halford and D.J. Thorne for technical input and review, B.J. Krall for her patient and efficient editing, C.L. Gist for word processing, and C.A. Little for PAG management. 


\section{ABSTRACT}

An independent assessment of the remediation of the BORAX-V (Boiling Water Reactor Experiment) turbine building at the Idaho National Engineering Laboratory (INEL), Idaho Falls, Idaho, was accomplished by the Oak Ridge National Laboratory Pollutant Assessments Group (ORNL/PAG). The purpose of the assessment was to confirm the site's compliance with applicable Department of Energy guidelines. The assessment included reviews of both the decontamination and decommissioning Plan and data provided from the pre- and post-remedial action surveys and an independent verification survey of the facility.

The independent verification survey included determination of background exposure rates and soil concentrations, beta-gamma and gamma radiation scans, smears for detection of removable contamination, and direct measurements for alpha and beta-gamma radiation activity on the basement and mezzanine floors and the building's interior and exterior walls. Soil samples were taken, and betagamma and gamma radiation exposure rates were measured on areas adjacent to the building.

Results of measurements on building surfaces at this facility were within established contamination guidelines except for elevated beta-gamma radiation levels located on three isolated areas of the basement floor. Following remediation of these areas, ORNL/PAG reviewed the remedial action contractor's report and agreed that remediation was effective in removing the source of the elevated direct radiation.

Results of all independent soil analyses for ${ }^{60} \mathrm{Co}$ were below the detection limit. The highest ${ }^{137} \mathrm{Cs}$ analysis result was $4.6 \mathrm{pCi} / \mathrm{g}$; this value is below the INEL site-specific guideline of $10 \mathrm{pCi} / \mathrm{g}$.

Based on data from the post-remedial action report and the independent verification survey, the radiologic condition of the BORAX-V turbine building conforms to the guidelines outlined by the Formerly Utilized Sites and Surplus Facilities Management Programs for surface and soil contamination. 


\section{CONFIRMATORY RADIOLOGICAL SURVEY \\ OF THE BORAX-V TURBINE BUILDING \\ IDAHO NATIONAL ENGINEERING LABORATORY \\ IDAHO FALLS, IDAHO}

\section{INTRODUCTION}

\subsection{TASK DESCRIPTION}

The Oak Ridge National Laboratory Pollutant Assessments Group (ORNL/PAG) was selected as the independent verification contractor (IVC) for the Boiling Water Reactor Experiment (BORAX)-V turbine building by the Decontamination and Decommissioning Branch, Division of the Northwestern Area Programs, Office of Environmental Restoration and Waste Management of the Department of Energy (DOE). As a part of its quality assurance program, DOE requires independent (third party) verifications of the effectiveness of remediations conducted within the Formerly Utilized Sites Remedial Action Program (FUSRAP) and the Surplus Facilities Management Program (SFMP) (U.S.DOE 1988).

Independent verification of the remediation of the BORAX-V turbine building addressed the radiological condition of the building foundation and surrounding soils prior to demolition. The primary nuclides of interest at the turbine building were ${ }^{137} \mathrm{Cs}$ and ${ }^{60} \mathrm{Co}$. Tasks required by FUSRAP protocol for verification and certification included reviews of plans, procedures, and remedial actions. On-site visits and surveys involving direct measurements and sampling were also conducted to determine that all levels are below applicable guidelines. ORNL/PAG is responsible for archiving representative samples of the site, as well as producing this final verification report that becomes part of the final certification docket. 
The docket contains documentation verifying that the site is not contaminated with radioactive residues that may present a radiological hazard to the general public (U.S.DOE 1988).

This independent verification is considered a partial verification of the BORAX.V facility since the reactor building is scheduled for decontamination and decommissioning in fiscal year (FY) 1994.

\subsection{SITE HISTORY}

The BORAX facility, located in the southwestern part of the Idaho National Engineering Laboratory (INEL), was the site for reactor experiments conducted between 1951 and 1964. The experiment series began with BORAX-I, an opentop boiling water reactor. This reactor was buried in place in 1953. Another site northeast of BORAX-I was chosen for subsequent experiments. The BORAX-II, -III, -IV, and -V experiments were conducted on the same site as the existing BORAX-V facility (Fig. 1). On December 20, 1951, EBR-1 was the first nuclear reactor to generate electricity. On July 17, 1955, BORAX-II gained historical significance as the first nuclear reactor to supply electricity to a city: Arco, Idaho (EG\&G 1990).

All BORAX experiments, except BORAX-I, were h/sused in two main buildings: the reactor building (AEF-601) and the turbine building (AEF-602), later designated as buildings 717 and 718 respectively. These buildings were constructed of sheet metal over steel frames. A wooden cooling tower and guard post, designated as buildings $719 ?-109$ respectively, were also originally part of the facility. The turbine building contained a 1926 Westinghouse turbine-generator and associated process piping, instrumentation, and testing loops.

The BORAX-V facility was designated for decommissioning in FY 1985; decommissioning tasks were performed from FY 1985 through FY 1989 (EG\&G 1990). A radiation survey conducted in 1989 on the turbine and associated components showed that the major radionuclides present were ${ }^{137} \mathrm{Cs}$ and ${ }^{60} \mathrm{Co}$. During FY-1991, the turbine, condenser, and associated piping were removed, 


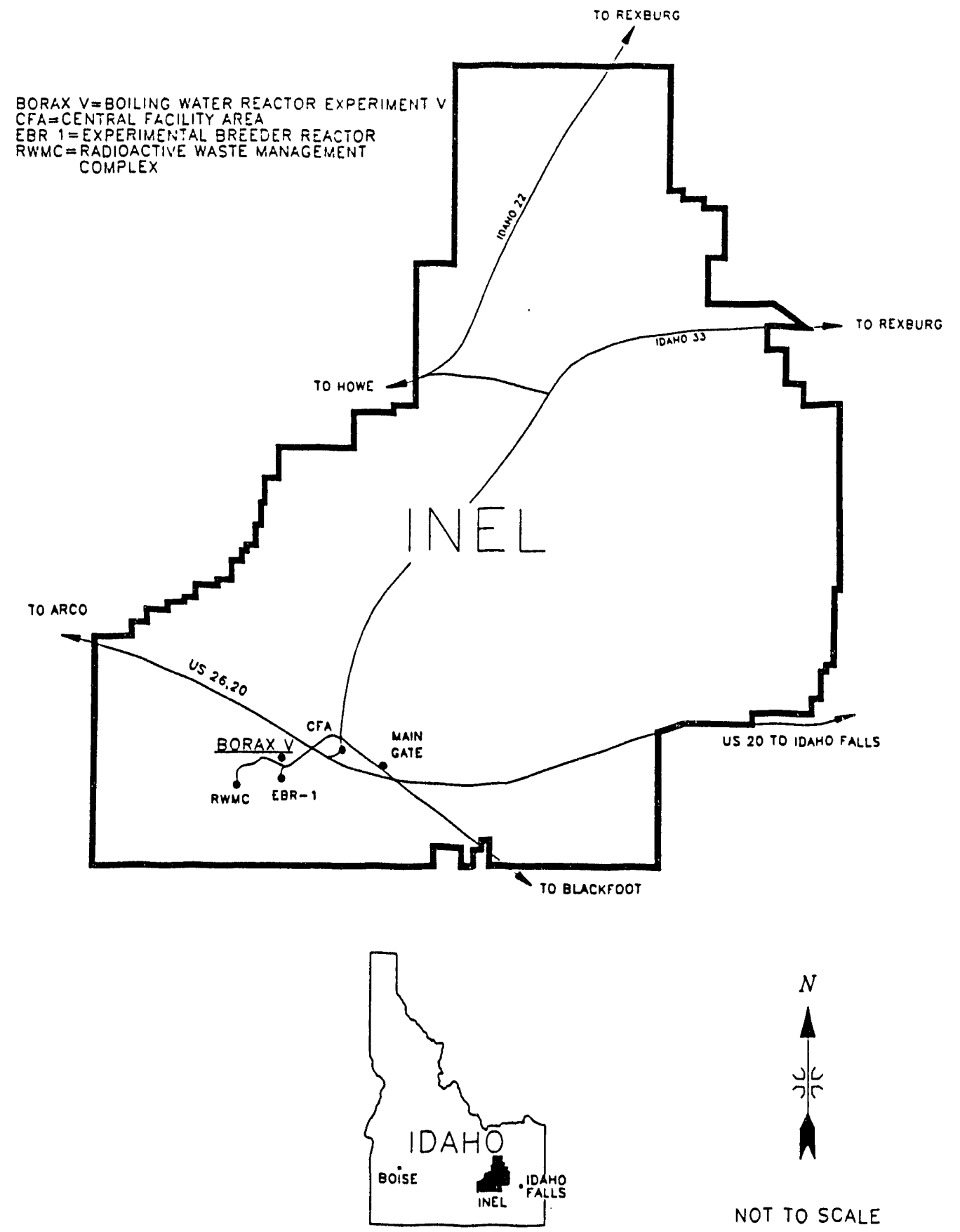

Fig. 1. INEL, showing location of BORAX-V site. 
from the turbine building. The walls of the building were also removed, leaving the mezzanine floor concrete pad, concrete walls, and basement walls, on slab and foundation to be demolished in place and backfilled. Early in FY-1992, portions of the concrete were decontaminated by means of concrete chipping in areas of suspected contamination.

Upon completion of remediation, a post-remediation survey was performed by EG\&G to demonstrate compliance with the clean-up guidelines. The postremediation survey report is presented as Appendix A.

\section{INDEPENDENT VERIFICATION PROCESS}

\section{DOCUMENT REVIEW}

Radiological characterization reports, engineering drawings, and postremediation survey documents were reviewed for general thoroughness and accuracy. Data were evaluated to ensure that areas exceeding guidelines were identified and remediated.

Information concerning radiologic contamination of the turbine building foundation was taken from an internal EG\&G technical report (EG\&G 1990) and from surveys conducted during remediation by EG\&G.

The general process for independent verification of the BORAX-V facility followed the FUSRAP protocol (U.S.DOE 1988); verification guidelines were based on DOE Order 5400.5, Radiation Protection of the Public and the Environment (U.S.DOE 1990). This document lists soil concentration guidelines for thorium and radium, surface contamination guidelines, and methods for determining site-specific authorized limits for radionuclides in air, water, and soil. The primary guidelines used by ORNL for this verification are the surface contamination guidelines for beta-gamma radiation emitters (Table 1). 
Table 1. Surface Contamination Guidclines, DOE Order 5400.5

\begin{tabular}{|c|c|c|c|c|}
\hline \multicolumn{2}{|c|}{ Radionuctides } & \multicolumn{3}{|c|}{$\begin{array}{l}\text { Allowable Total Residual Surface Contamination } \\
\left(\text { dom/100 } \mathrm{cm}^{2}\right)^{y}\end{array}$} \\
\hline \multicolumn{2}{|c|}{$\begin{array}{l}\text { Transuranics, }{ }^{125} \mathrm{I},{ }^{129} \mathrm{I} \\
{ }^{26} \mathrm{Ra},{ }^{22} \mathrm{Ac},{ }^{20} \mathrm{Ra} \\
{ }^{258} \mathrm{Th},{ }^{230} \mathrm{Th},{ }^{231} \mathrm{~Pa}\end{array}$} & RESERVED & RESERVED & RESERVED \\
\hline \multicolumn{2}{|c|}{$\begin{array}{l}\text { Th- Natural, }{ }^{90} \mathrm{Sr},{ }^{126} \mathrm{I} \\
{ }^{131} \mathrm{I},{ }^{133} \mathrm{I},{ }^{23} \mathrm{Ra} \\
{ }^{24} \mathrm{Ra},{ }^{232} \mathrm{U},{ }^{232} \mathrm{Th}\end{array}$} & 1,000 & 3,000 & 200 \\
\hline \multicolumn{2}{|c|}{$\begin{array}{l}\mathrm{U}-\mathrm{Natural},{ }^{235} \mathrm{U},{ }^{238} \mathrm{U} \mathrm{I} \\
\text { and associated decaj' } \\
\text { product, alpha emitters. }\end{array}$} & 5,000 & 15,000 & 1,000 \\
\hline \multicolumn{2}{|c|}{$\begin{array}{l}\text { Beta-gamm i emitters } \\
\text { (radionuclides with decay } \\
\text { modes other than alpha } \\
\text { einission or spontanenus } \\
\text { fission) cxcept }{ }^{90} \mathrm{Sr} \text { and } \\
\text { others noted above.? }\end{array}$} & 5,000 & 15.000 & 1,000 \\
\hline$\overline{1}$ & \multicolumn{4}{|c|}{$\begin{array}{l}\text { As used in this table, dpm (disintegrations per minute) means the rate } \\
\text { of emission by radioactive material as determined by correcting the } \\
\text { counts per minute measured by an appropriate detector for } \\
\text { background, efficiency, and geometric factors associated with the } \\
\text { instrumentation. }\end{array}$} \\
\hline 2 & \multicolumn{4}{|c|}{$\begin{array}{l}\text { Where surface contamination by both alpha- and heta-gamma-emitting } \\
\text { radionuclides exists, the limits established for alpha- and beta-gamma- } \\
\text { emitting radionuclides should apply independently. }\end{array}$} \\
\hline 3 & \multicolumn{4}{|c|}{$\begin{array}{l}\text { Measurements of average contamination should not be averaged over an area } \\
\text { of more than } 1 \mathrm{~m}^{2} \text {. For objects of less surface area, the average should be } \\
\text { derived for each such object. }\end{array}$} \\
\hline 4 & \multicolumn{4}{|c|}{$\begin{array}{l}\text { The average and maximum dose rates associated with surface contamination } \\
\text { resulting from beta-gamma emitters should not exceed } 0.2 \mathrm{mrad} / \mathrm{h} \text { and } \\
1.0 \mathrm{mrad} / \mathrm{h} \text {, respectively, at } 1 \mathrm{~cm} \text {. }\end{array}$} \\
\hline
\end{tabular}


Table 1. (continued)

5/ The maximum contamination level applies to an area of not more than $100 \mathrm{~cm}^{2}$.

6) The amount of removable material per $100 \mathrm{~cm}^{2}$ of surface area should be determined by wiping an area of that size with dry filter or soft absorbent paper, applying moderate pressure, and measuring the amount of radioactive material on the wiping with an appropriate instrument of known efficiency. When removable contamination on objects of surface area less than $100 \mathrm{~cm}^{2}$ is determined, the activity per unit area should be based on the actual area and the entire surface should be wiped. It is not necessary to use wiping techniques to measure removable contamination levels if direct scan surveys indicate that the total residual surface contamination levels are within the limits for removable contamination.

7I This category of radionuclides includes mixed fission products, including the ${ }^{90} \mathrm{Sr}$ which is present in them. It does not apply to ${ }^{90} \mathrm{Sr}$ which has been separated from the other fission products or mixtures where the ${ }^{90} \mathrm{Sr}$ has been enriched. 
Analysis results for soil samples were compared to the results for background samples as well as the derived concentration values generated by EG\&G and listed in Development of Criteria for Release of Idaho National Engineering Laboratory Sites Following Decontamination and Decommissioning (EG\&G 1986). This report states that the primary nuclide of interest, ${ }^{137} \mathrm{Cs}$, shall not exceed $10 \mathrm{pCi} / \mathrm{g}$. Cobalt60 has a limit of $4 \mathrm{pCi} / \mathrm{g}$, and ${ }^{238} \mathrm{U}$ has a limit of $200 \mathrm{pCi} / \mathrm{g}$. The guidelines for ${ }^{226} \mathrm{Ra}$ are from DOE Order 5400.5: concentrations of ${ }^{226} \mathrm{Ra}$ in soil shall not exceed $5 \mathrm{pCi} / \mathrm{g}$ above background in the first $15 \mathrm{~cm}$ and $15 \mathrm{pCi} / \mathrm{g}$ above background in subsequent $15-\mathrm{cm}$ soil layers when averaged over $100 \mathrm{~m}^{2}$.

\section{FIELD SURVEY}

A team from ORNL/PAG visited the BORAX-V site and performed a scoping inspection in July 1991. An independent verification survey plan was developed based on both this inspection and the remediation survey data. ORNL/PAG conducted an independent confirmatory survey of the turbine building foundation and adjacent land during November 20 to 27 and December 9 to 15, 1991. The survey team performed visual inspections, determined background radionuclide levels and exposure rates, established survey grids, performed gamma and betagamma radiation scans, took smears for detection of removable activity, made direct beta-gamma and alpha radiation measurements, and collected surface samples $(0$ to $15 \mathrm{~cm}$ ) on designated background soils and soils surrounding the building foundation. Duplicate readings were taken every tenth reading as a quality control measure. Data were evaluated and compared to guidelines set forth in DOE Order 5400.5 (U.S.DOE 1990).

The survey and measurement procedures used are from the ORNL/PAG procedures manual: TE-021, TE-022, TE-025, TE-026, TE-027, TE-028, TE-034 (ORNL 1990). An inventory of the survey equipment used is listed in Appendix B. 


\section{Background Radiation Investigation}

Six soil samples were collected from areas 0.5 to $10 \mathrm{~km}$ from the site to establish background concentrations of radionuclides for comparison purposes (Fig. 2). Background gamma radiation exposure rate levels were measured at $1 \mathrm{~m}$ above the surface at background sampling locations using a pressurized ionization chamber (PIC) (Table 2). A corresponding gamma radiation measurement was taken with a sodium iodide ( $\mathrm{NaI}$ ) gamma radiation detector coupled to a ratemeter reading in thousand counts per minute $(\mathrm{kcpm})$. The same procedure was followed at 10 locations at the turbine building site to determine the site-specific gamma radiation exposure rate (Fig. 3, Table 2). The measurements at the turbine building site were used to convert counts to exposure rates in microroentgens per hour $(\mu R / h)$ as outlined in Procedure TE-022 (ORNL 1990). The conversion formula was $\mu \mathrm{R} / \mathrm{h}=\mathrm{kcpm} / 0.34$. This factor was used to convert all gamma radiation measurements taken at the site from counts to $\mu R / h$.

\section{2 .2 Exterior Survey}

\section{Land Surrounding Turbine Building}

A $5 \times 5 \mathrm{~m}$ grid was established originating at the northwest corner of the building and extending $10 \mathrm{~m}$ away from all sides of the building (Fig. 4). An exterior gamma radiation scan of the ground surrounding the building was performed. Piles of gravel had been dumped adjacent to the west side of the structure, thereby precluding a complete scan in that area. Also, during remediation, the ground to the south of the building had been excavated to remove contaminated piping. The survey team was unable to effectively scan these areas due to unsafe slope conditions. 


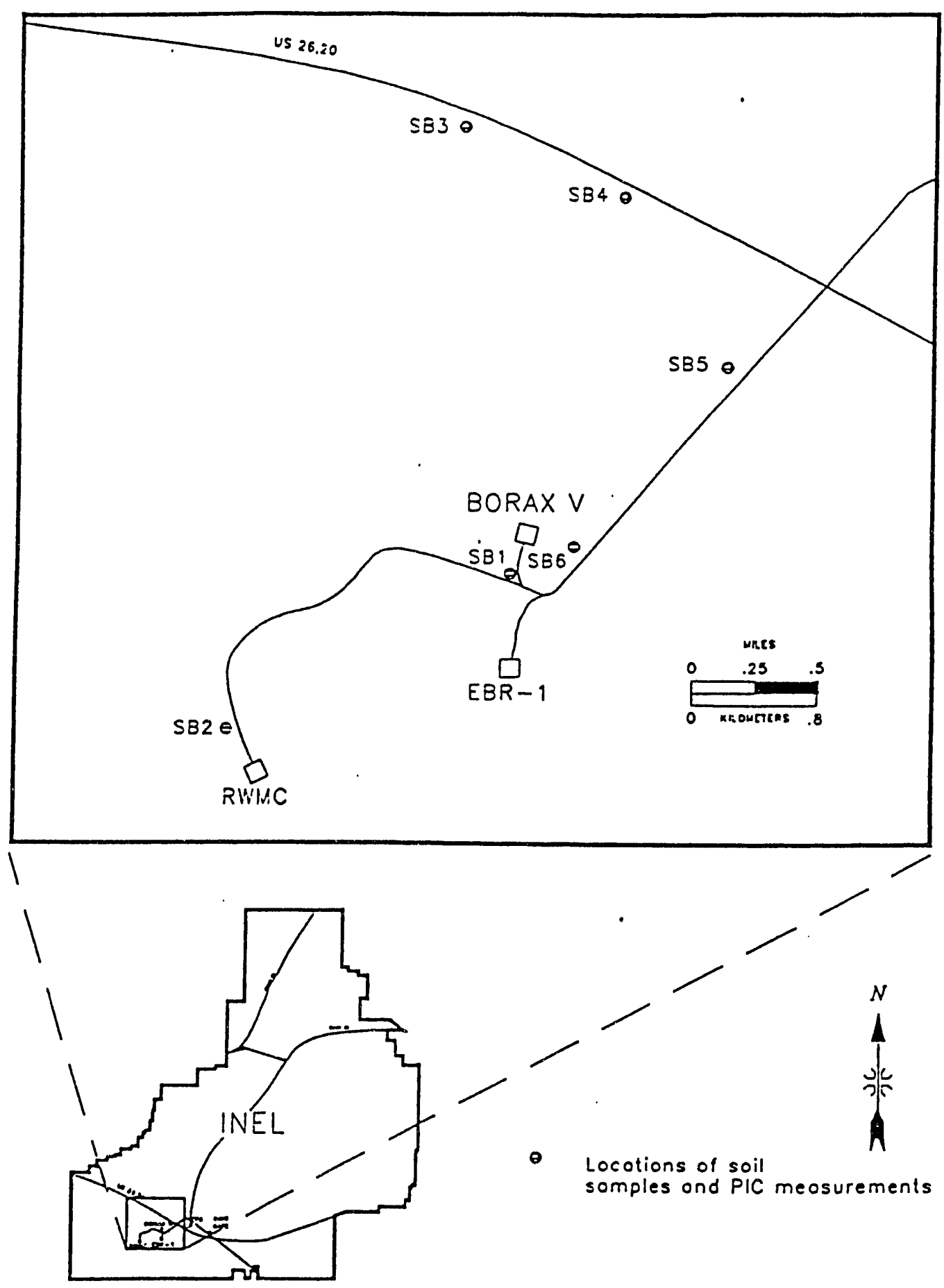

Fig. 2. Sampling locations for background concentrations. 


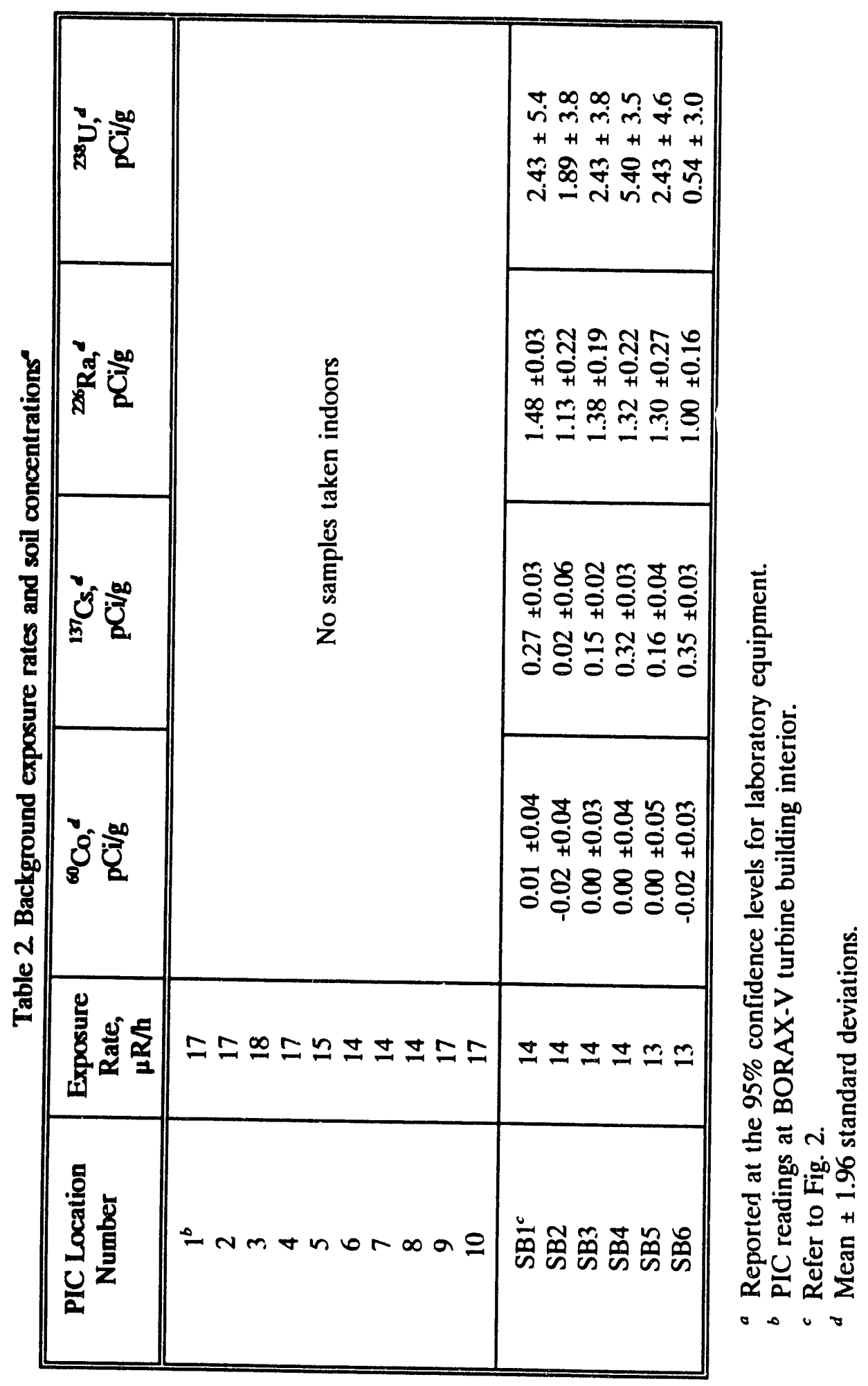



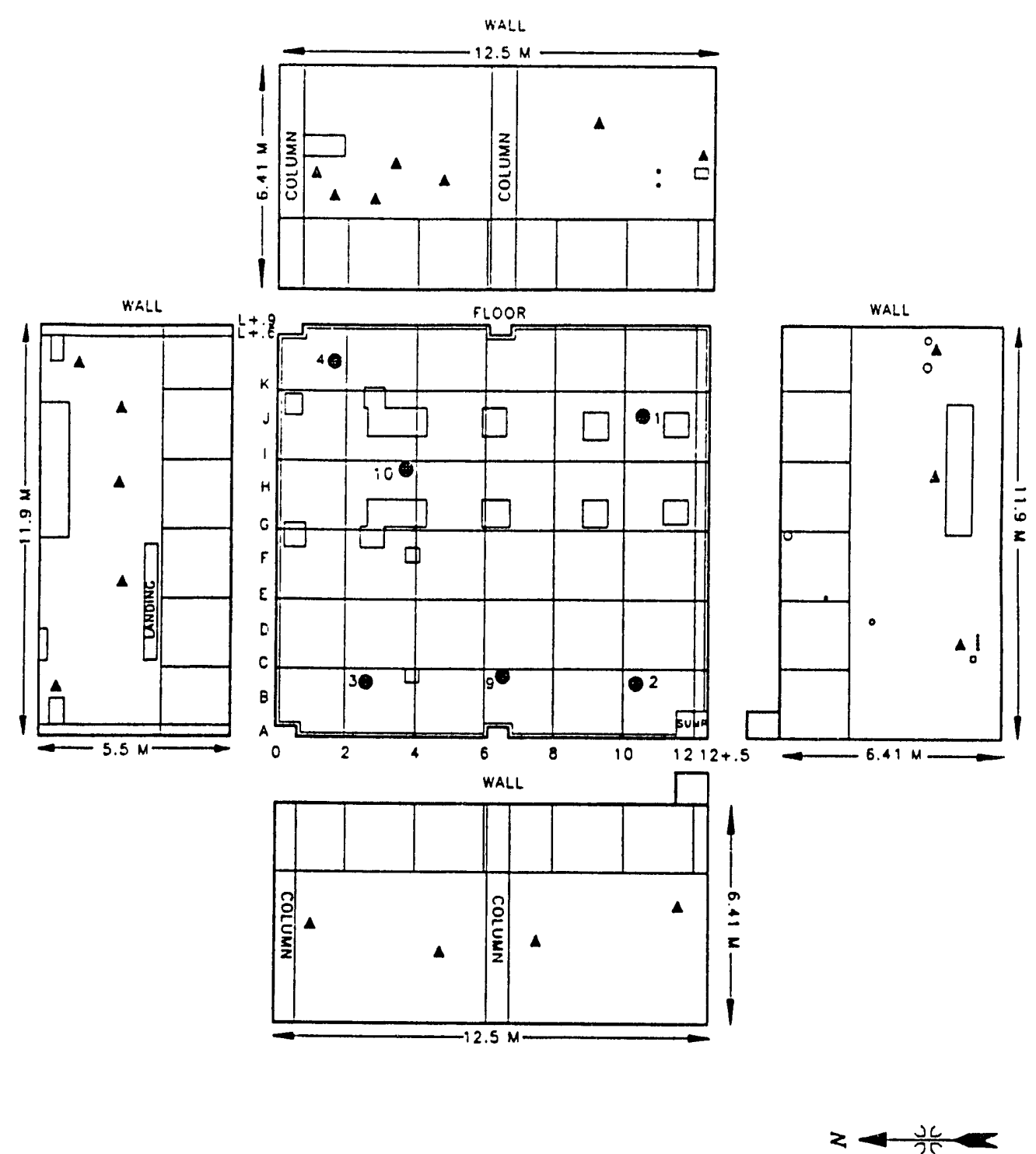

ALL GRID BLOCKS

A UPPER WALL

BETA-GAMMA RADIATION MEASUREMENTS

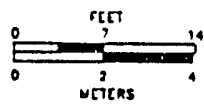

- pic measurement locations

Fig. 3. Turhine building interior walls and floor, showing PIC and additional fixed-point measurement locations. 


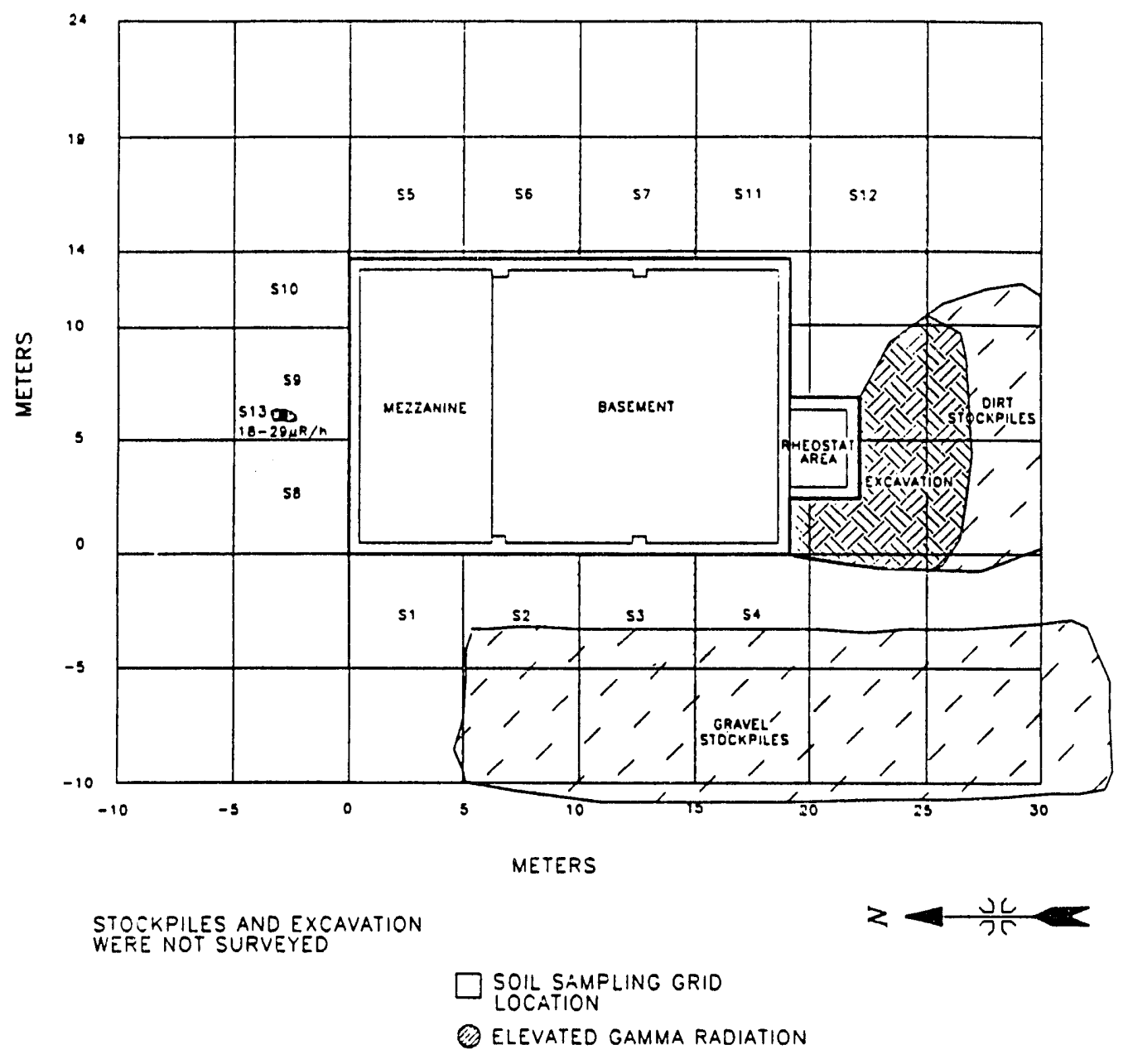

Fig. 4. Exterior grid, showing sampling locations and elevated gamma radiation region. 
Fixed-point measurements for beta-gamma and gamma radiation exposure rates were taken at the intersection of all grid points. Gamma radiation exposure rate measurements were also taken at $1 \mathrm{~m}$ from the surface at selected grid intersections.

Composite soil samples collected at a depth of 0 to $15 \mathrm{~cm}$ were collected in twelve systematically selected grid blocks adjacent to the building (samples S1 to S12, Fig. 4). The samples were composited from plugs taken from the center of each selected grid block and at four points midway between the grid-block center and corners. In addition, one grab sample (S13) was taken at the highest betagamma radiation measurement from a region identified during the gamma radiation scan.

\section{Exterior Walls}

A $1 \times 2 \mathrm{~m}$ grid was established originating in the northwest corner of the turbine building (Fig. 5). A beta-gamma radiation scan was performed on all walls except a portion of the south end of the building, where excavation precluded safely surveying the upper walls.

Fixed-point measurements for alpha and beta-gamma radiation were taken at five locations in each accessible grid block at the south end of the building. As a result of these readings and the beta-gamma radiation scan, it was deemed unnecessary to continue extensive fixed measurements on all exterior walls. Single fixedpoint measurements were taken for alpha and beta-gamma radiation in each of the remaining grid blocks. The walls and floor inside the rheostat area were also scanned; no beta-gamma radiation contamination was detected (Fig. 4) (Table 3).

\section{2 .3 Interior Survey}

The turbine building interior consisted of a mezzanine level, slab-on-grade, in addition to a basement level. The floor of the basement had numerous protruding concrete supports. A $10-\mathrm{cm}$-wide trench at the base of the walls discharged to a 

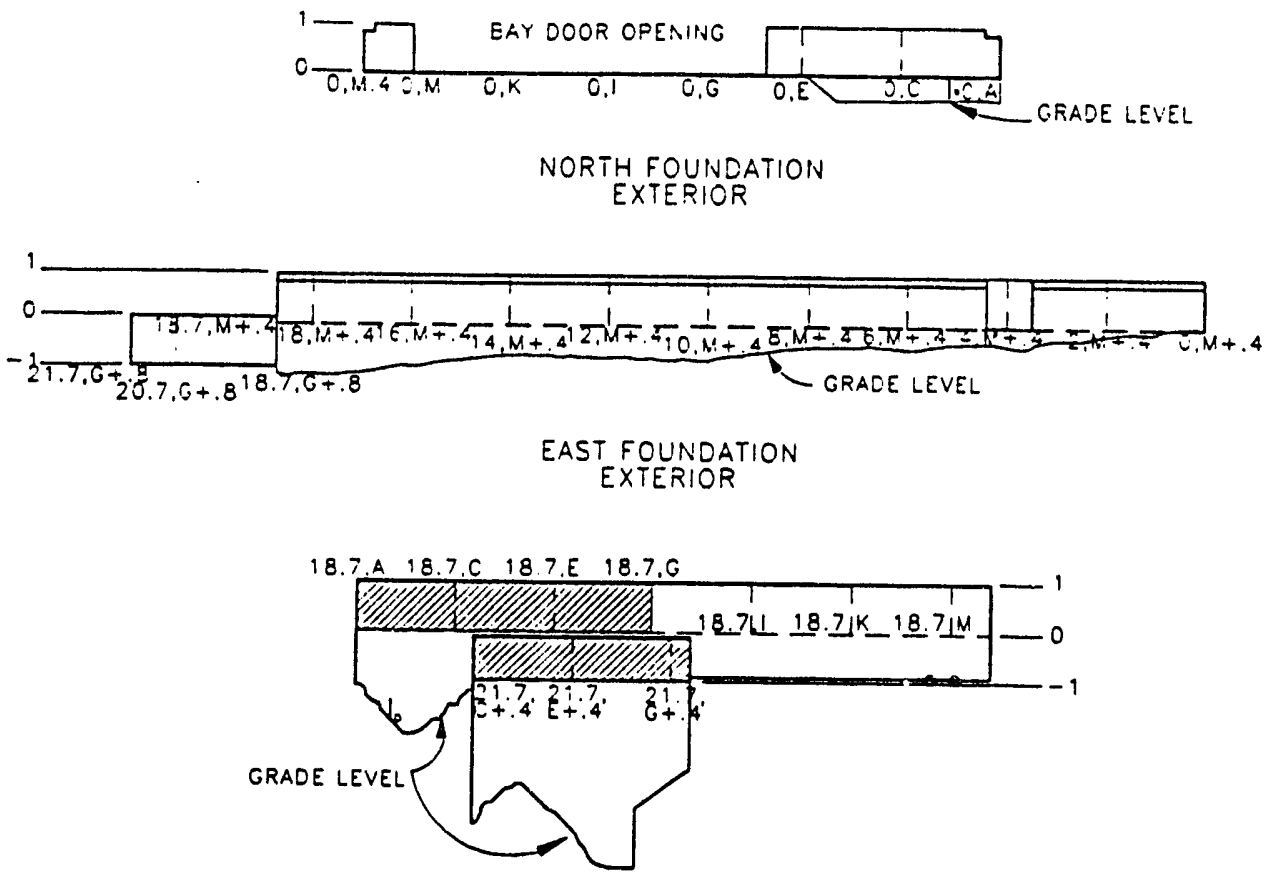

SOUTH FOUNDATION EXTERIOR

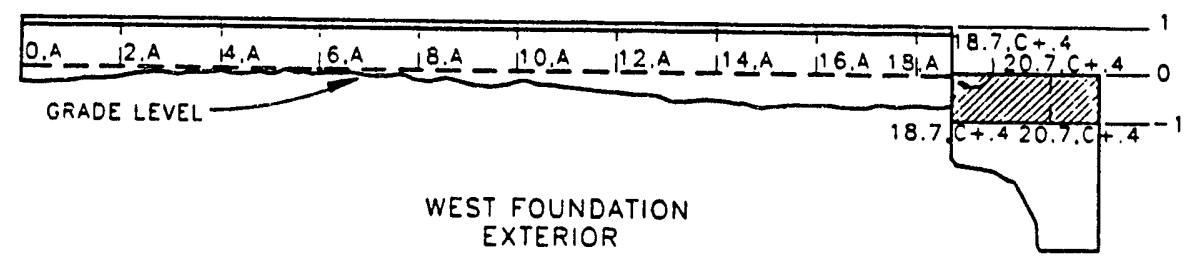

EXTERIOR

GRIO BLOCKS

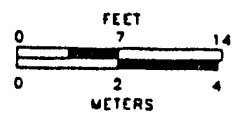

Fig. 5. Exterior wall grids, side view. 


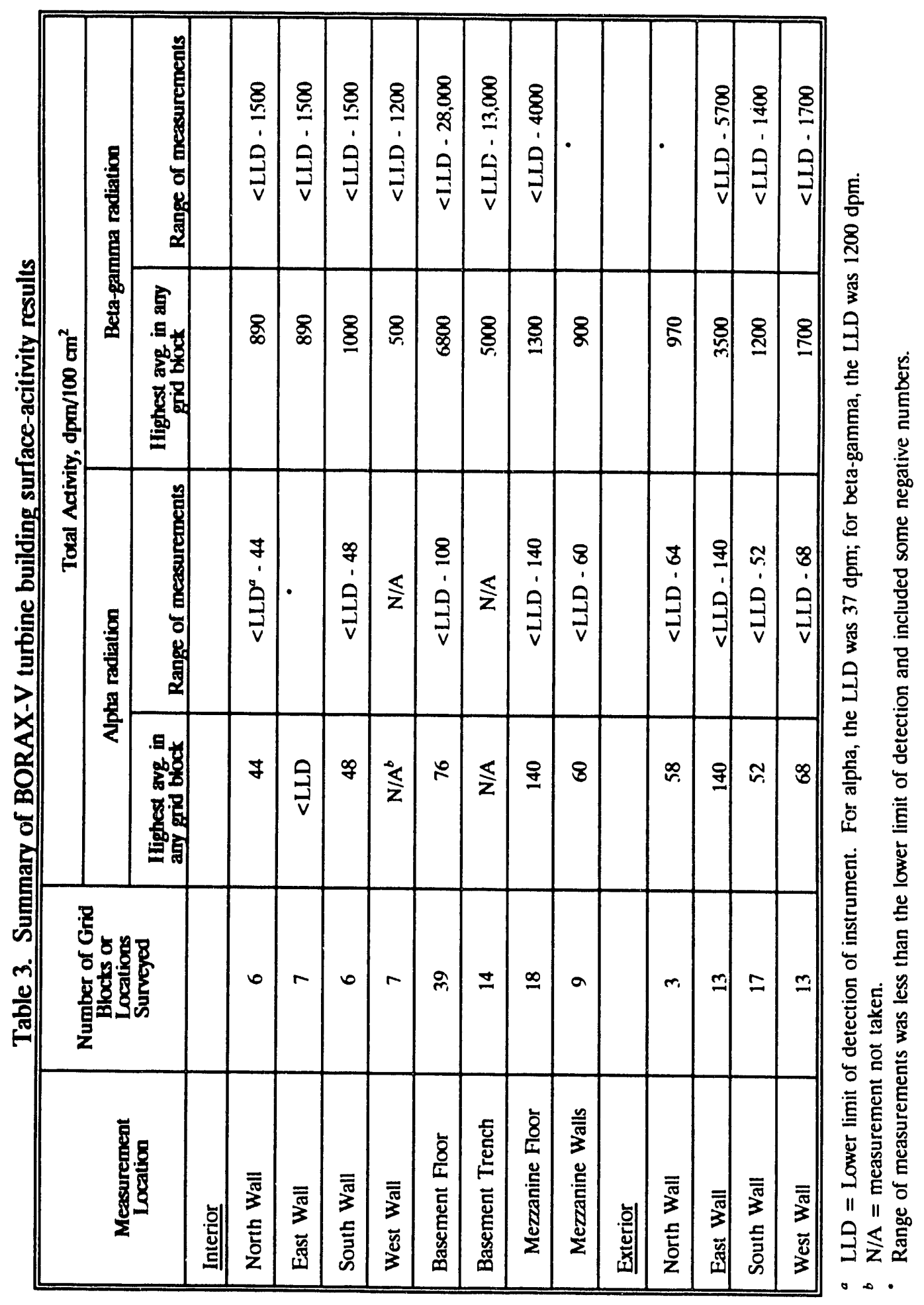


sump in the southwest corner of the room. At some locations around the walls, exposed pipes and floor supports remained.

A $2 \times 2 \mathrm{~m}$ alphanumeric grid originating in the northwest corner was established on the floors and up the basement walls (to $2 \mathrm{~m}$ ) (Fig. 3).

\section{Mezzanine}

A $2 \times 2 \mathrm{~m}$ alphanumeric grid originating in the northwest corner was established for the mezzanine (Fig. 6). A beta-gamma radiation gas proportional counter floor monitor coupled to a scaler/ratemeter with audible indicator was used to scan the accessible area of the mezzanine. Areas inaccessible to the floor monitor were scanned using a Geiger-Mueller (GM) thin-window pancake probe coupled to a scaler/ratemeter. Scans using NaI gamma radiation scintillation detectors coupled to ratemeters were also performed in the pipe chase areas and on the floor.

Fixed-point readings for alpha and beta-gamma radiation were taken at four locations in each grid block (Table 3). These grid blocks included the pipe chase area.

Floor

A beta-gamma radiation gas proportional counter floor monitor was used to scan accessible areas of the floor. The remaining area, which included all concrete supports, the trench, and the sump, were scanned using beta-gamma radiation GM thin window pancake probes attached to scaler/ratemeter. In addition, a gamma radiation scan of the floor was performed using scintillometers.

Direct measurements for alpha and beta-gamma radiation activity levels were systematically made at four equidistant points, midway between the center and corners in each grid block. Smears for detection of removable contamination were taken at the location of the highest direct reading in each grid block. These results are summarized in Table 3. 

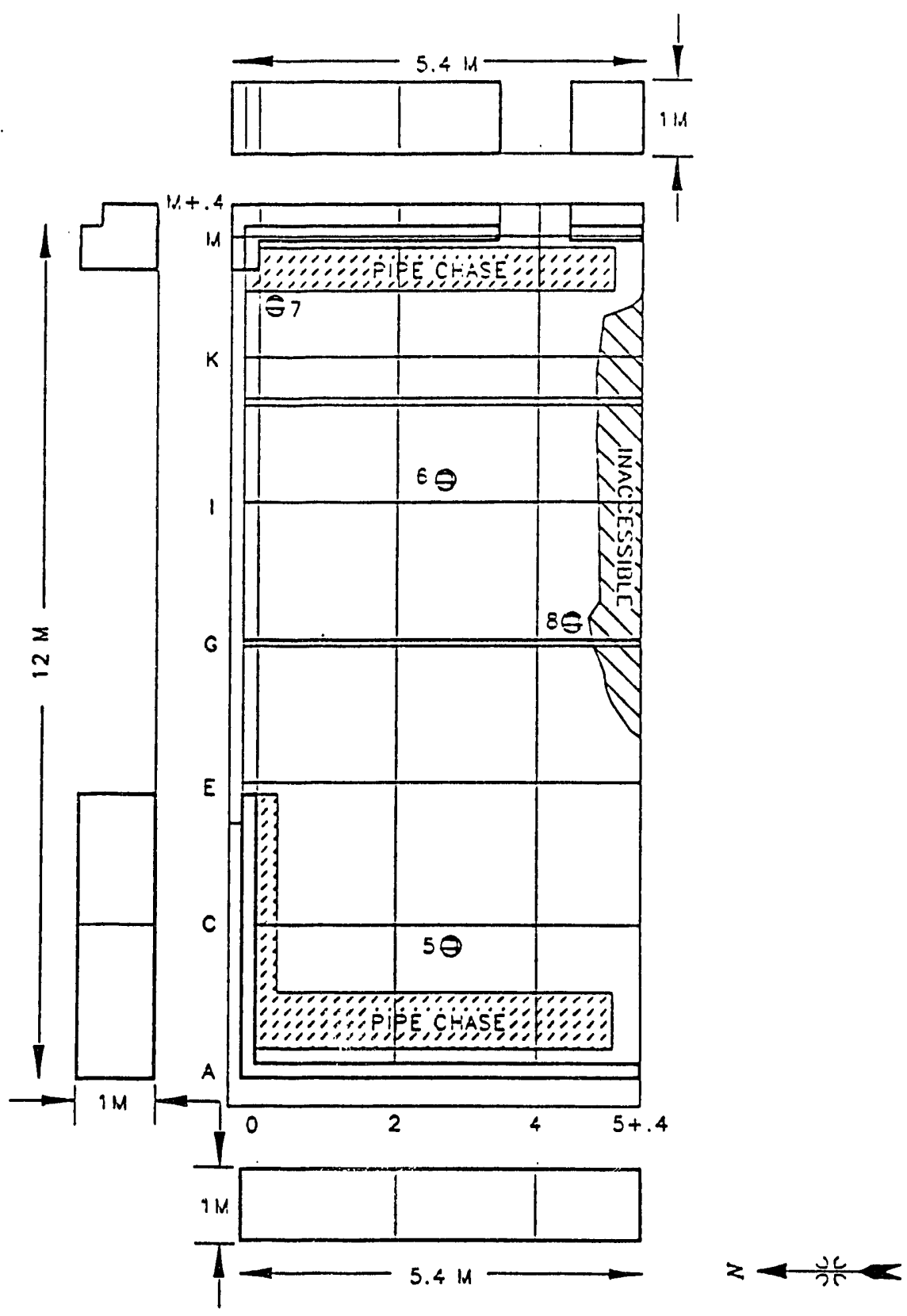

ALL GRID BLOCKS V'ERE SURVEYED

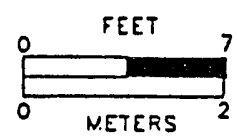

$\theta$ PIC MEASUREMENT LOCATIONS

Fig. 6. Turbine building mezzanine grid, showing PIC measurement locations. 


\section{Walls}

The walls of the basement were scanned to a height of $2 \mathrm{~m}$ with beta-gamma radiation pancake probes coupled to scaler/ratemeters. In addition, all areas on the walls with pipes, floor supports, discoloration, or staining were scanned. These additional wall locations are shown in Fig. 3.

Direct measurements for alpha, beta, and gamma radiation activity levels were made in the same manner as were the floor measurements. Fixed-point measurements were taken at four locations per grid block for beta-gamma radiation readings and at one location per grid block for alpha radiation readings. Smears for detection of removable contamination were taken at the location of the highest direct reading in each grid block. These results are summarized in Table 3.

Trench

A trench $10-\mathrm{cm}$ wide and $5-\mathrm{cm}$ deep encompassed the perimeter of the basement floor, ending in a sump located in the southwest corner of the basement. After surveying the floors and walls, a 10-cm-wide region of suspected contamination along the wall and floor was delineated. For each 2-m grid block, three sets of alpha, beta, and gamma radiation measurements were taken: one at $10 \mathrm{~cm}$ up from the trench, one at $10 \mathrm{~cm}$ out from the trench, and one within the trench itself. This method was repeated for the full length of the trench. The sump was scanned for beta-gamma radiation; no elevated readings were detected (Table 3). 


\section{FINDINGS AND RESULTS}

\subsection{DOCUMEN: REVIEW}

ORNL revieued the post decontamination and decommissioning survey of the BORAX-V lutbine building (EG\&G 1990) prepared by EG\&G as part of the confirmatory activities. The information provided was not sufficient to determine if contamination still remained at the BORAX-V Turbine Building site. The data was reported in counts per minute (cpm). These units give an indication of relative "cleanness." However, unless they are converted to disintegrations per minute (dpm) per surface area, cpm measurements cannot be used as evidence that the building surfaces meet FUSRAP/SFMP guidelines for unrestricted use. After obtaining the necessary inforrition, ORNL was able to complete the independent verification plan.

ORNL also reviewed the data and survey results of the decontamination of the hot spots identilied during the independent verifica:ion survey. These results were compared to the established guidelines. This is discussed further in Sect. 3.4. ORNL concurs that the "Final Report of the Decontamination and Decommissioning of the Borax-V Facility Turbine Building" provides an adequate summation of the current radiologica! status of the site.

\subsection{BACKGROUND RADIATZON MEASUREMENTS}

PIC measurements for gamma radiation expcsure rates at the six background locations (SB1 to SB6. Fig. 2) ranged from 13 to $14 \mu \mathrm{R} / \mathrm{h}$. All soil samples were sent to ORNL in Oak Ridge. Tenn., for ${ }^{137} \mathrm{Cs},{ }^{60} \mathrm{Co},{ }^{238} \mathrm{U}$, and ${ }^{26} \mathrm{Ra}$ radionuclide analyses using gamma spectroscopy. Results of the analyses for the six background locations and the exposure rates are presented in Table 2. PIC readings taken at the turbine building were slightly higher, yielding gamma exposure rates ranging from $14 \mu \mathrm{R} / \mathrm{h}$ in the mezzanine area to $18 \mu \mathrm{R} / \mathrm{h}$ in the basement (Table 2). This 
was attributed to the emanation of the gamma radiation from several directions since the measurements were periormed in a concrete basement.

\subsection{EXTERIOR RADIATION MEASUREMENTS}

The exterior survey, $u_{i}$ ig gamma radiation scintillation detectors coupled to ratemeters, revealed gamma radiation exposure rates ranging from $i$ ? to $18 \mu R / h$. One area, approximately $1 \mathrm{~m}^{2}$ and located just north of the mezzanine area, had a gamma radiation exposure rate range of 18 to $29 \mu \mathrm{R} / \mathrm{h}$ (Fig. 4). Soil sample S13 was taken at this location.

Results of radionuclide analyses of soil samples taken in each grid block adjacent to the turbine building and at the slightly elevated location identified by the gamma radiation scan are presented in Table 4. All concentrations were below the guidelines of $4 \mathrm{pCi} / \mathrm{g}$ for ${ }^{60} \mathrm{Co}, 10 \mathrm{pCi} / \mathrm{g}$ for ${ }^{137} \mathrm{Cs}, 5 \mathrm{pCi} / \mathrm{g}$ for ${ }^{206} \mathrm{Ra}$, and $200 \mathrm{pCi} / \mathrm{g}$ for ${ }^{238} \mathrm{U}$. ORNL/PAG has archived all soil samples and will maintain custody of these samples for five years after certification of the BORAX-V turbine building has been achieved.

A summary of exposure rate measurements for gamma and beta-gamma radiation taken at the intersections of grid blocks surrounding the turbine building is presented in Table 5. All measurements were below the esiablished guidelines.

\subsection{TURBINE BUILDING RADIATION MEASUREMENTS}

Gamma radiation exposure rate measurements on the mezzanine and basement foor, using scintillation detectors coupled to ratemeters, yielded exposure rates ranging from 18 to $21 \mu \mathrm{R} / \mathrm{h}$.

A summary of the results of the fixed-point measurements for alpha and beta-gamma radiation are presented in Table 3. Instrument background measurements of $60 \mathrm{cpm}$ for beta-gamma radiation were noted. Instrument 


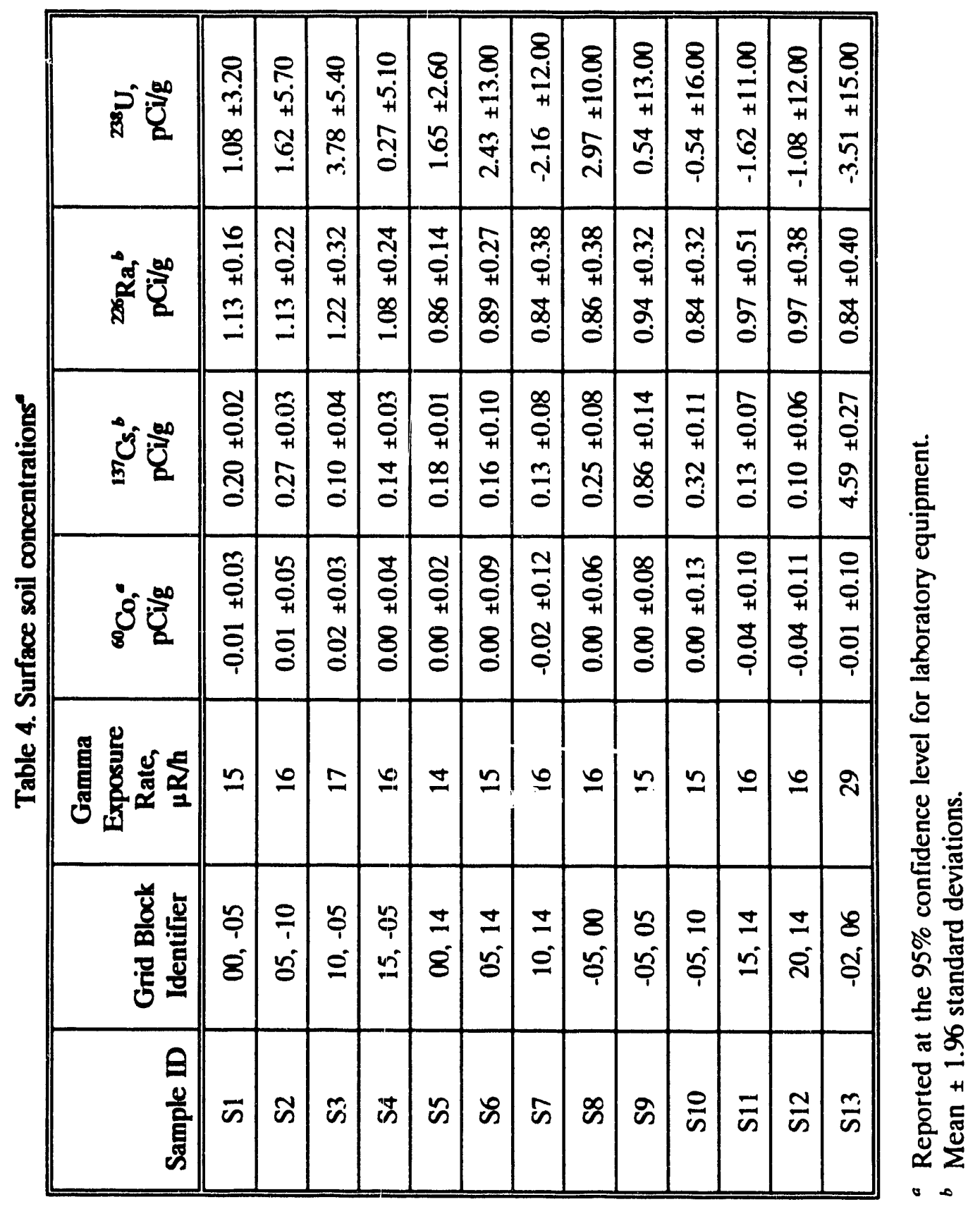


Table 5. Summary of exterior exposure rates

\begin{tabular}{||l|c|c|c|}
\hline & $\mathbf{n}$ & $\overline{\mathbf{x}}$ & $s$ \\
\hline $\begin{array}{l}\text { Gamma radiation, } \\
\mathrm{R} / \mathrm{h} \text { at surface }\end{array}$ & 65 & 16 & 2 \\
\hline $\begin{array}{l}\text { Gamma radiation, } \\
\mu \mathrm{R} / \mathrm{h} \text { at } 1 \mathrm{~m}\end{array}$ & 14 & 15 & 1 \\
\hline $\begin{array}{l}\text { Beta-gamma radiation, } \\
\text { dpm/100 } \mathrm{cm}^{2}\end{array}$ & 65 & 790 & 320 \\
\hline
\end{tabular}

$\mathrm{n}=$ number of measurements
$\overline{\mathbf{x}}=$ mean
$\mathrm{s} \quad=$ standard deviation.


background measurements for alpha radiation were $5 \mathrm{cpm}$. Portions of the drainage trench, floor, and walls adjacent to the trench showed elevated beta-gamma radiation count rates. These areas did not exceed DOE guidelines when averaged over $1 \mathrm{~m}^{2}$. All readings for alpha radiation on the interior and exterior surfaces were below applicable gu idelines.

Smear locations were selected as discussed in Sect. 2 to detect removable alpha and beta-gamma radiation activity. Results of these measurements are presented in Table 6. All smear readings were below established guidelines, and in many instances, the measurements were below the lower limit of detection (LLD) of the instrument. It should be noted that measurements below the LLD are very uncertain and probably invalid for verification purposes.

Beta-gamma radiation scans were performed with the knowledge that the guidelines were exceeded at $5,000 \mathrm{dpm}$ or $215 \mathrm{cpm}$. Therefore, all readings above $150 \mathrm{cpm}$ were carefully investigated for possible contamination. Three small regions on the basement floor exceeding the guidelines were identified. The locations of these regions are presented in Fig. 7 ; the readings are summarized in Table 7. Further remediation of these "hot spots" was performed by the remedial action contractor, and after review of the clean-up report of decontamination of the hot spots (Appendix $\mathrm{C}$ ), the turbine building was recommended for certification. A statement of verification has been issued by ORNL/PAG for the BORAX$\mathrm{V}$ turbine building (Appendix D).

\section{SUMMARY}

In order to document the adequacy of remedial actions, ORNL/PAG performed independent verification on the BORAX-V turbine building at INEL. Verification activities included document reviews, independent measurements, sampling, and confirmatory laboratory analyses. Field activities were performed during November and December 1991. Three small areas on the turbine building 
Table 6. Summary of interior removable contamination

\begin{tabular}{|c|c|c|c|c|c|c|}
\hline \multirow[b]{3}{*}{$\begin{array}{l}\text { Measurement } \\
\text { Location }\end{array}$} & \multicolumn{3}{|c|}{ Alpha Radiation } & \multicolumn{3}{|c|}{ Beta-gamma Radiation } \\
\hline & \multirow[b]{2}{*}{$\begin{array}{c}\text { Number of } \\
\text { Grid } \\
\text { Blocks or } \\
\text { Locations } \\
\text { Surveyed }\end{array}$} & \multicolumn{2}{|c|}{$\begin{array}{l}\text { Activity, } \\
\text { dpm/100 cm }\end{array}$} & \multirow[b]{2}{*}{$\begin{array}{c}\text { Number of } \\
\text { Grid Blocks } \\
\text { or Locations } \\
\text { Surveyed }\end{array}$} & \multicolumn{2}{|c|}{$\begin{array}{l}\text { Activity, } \\
\text { dpm/100 cm }\end{array}$} \\
\hline & & $\begin{array}{l}\text { Maximum } \\
\text { Reading }\end{array}$ & LLD & & $\begin{array}{l}\text { Maximum } \\
\text { Reading }\end{array}$ & LLD \\
\hline West wall & 16 & $<$ LLD & 22 & 16 & $<$ LLD & 118 \\
\hline North wall & 15 & $<$ LLD & 22 & 15 & $<$ LLD & 118 \\
\hline East wall & 14 & $<$ LLD & 22 & 14 & $<$ LLD & 118 \\
\hline South wall & 12 & $<$ LLD & 22 & 12 & $<$ LLD & 118 \\
\hline Floor & 40 & $<$ LLD & 22 & 40 & 160 & 118 \\
\hline
\end{tabular}

LLD = lower limit of detection of instrument. 


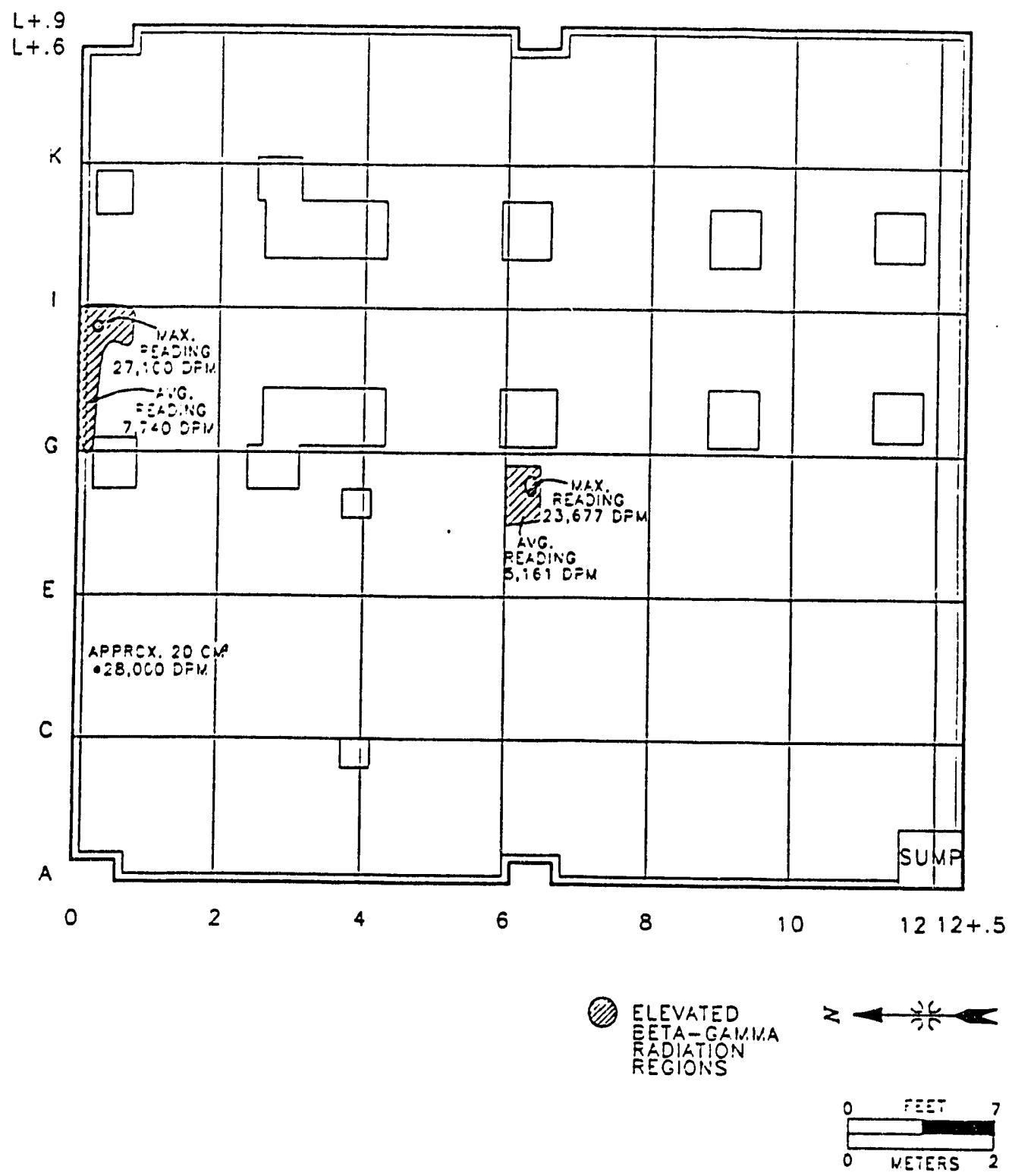

Fig. 7. Turbine building floor, showing elevated beta-gamma radiation regions. 


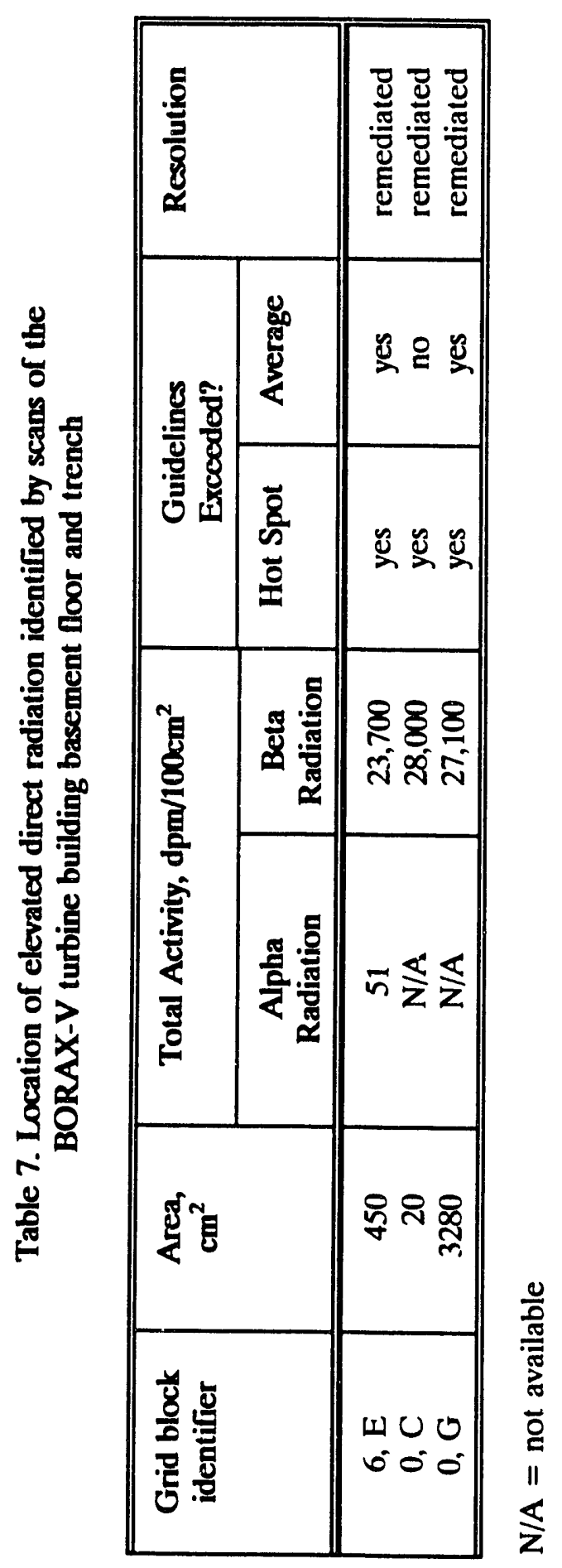


basement floor and trench that required further cleanup were identified. The three areas were remediated by EG\&G, and a post-decontamination survey was sent to ORNL/PAG (Appendix C). The independent verification survey confirmed that remedial action reduced contaminant levels below applicable guidelines prior to demolition and burial so that the public and environment are thereby protected. A statement of verification has been issued by ORNL/PAG for the BORAX-V turbine building (Appendix D). 


\section{REFERENCES}

EG\&G. 1986. Development of Criteria for Release of Idaho National Engineering Laboratory Sites Following Decontamination and Decommissioning. EGG2400. EG\&G Idaho, Inc., Idaho Falls, Idaho.

EG\&G. 1990. Decontamination and Decommissioning Plan for the BORAX-V Facility. PR-W-79-017, Revision 3. EG\&G Idaho, Inc., Idaho Falls, Idaho.

ORNL. 1990. Pollutant Assessments Group Procedures Manual. ORNL-6645. Health and Safety Research Division. Oak Ridge National Laboratory, Grand Junction, Colo.

U.S.DOE. 1988. Verification and Certification Protocol for the Formerly Utilized Sites and Surplus Facilities Management Programs. Office of Environmental Restoration, U. S. Department of Energy, Washington D.C.

U.S.DOE. 1990. Radiation Protection of the Public and the Environment. DOE Order 5400.5. U. S. Department of Energy, Washington, D.C. 
ACRONYMS, INITIALISMS, AND ABBREVIATIONS 
ACRONYMS, INITIALISMS, AND ABBREVIATIONS

$\begin{array}{ll}\text { BORAX } & \text { Boiling Water Reactor Experiment } \\ \text { cpm } & \text { counts per minute } \\ \text { DOE } & \text { Department of Energy } \\ \text { dpm } & \text { disintegrations per minute } \\ \text { FUSRAP } & \text { Formerly Utilized Sites Remedial Action Program } \\ \text { FY } & \text { fiscal year } \\ \text { GM } & \text { Geiger Mueller } \\ \text { INEL } & \text { Idaho National Engineering Laboratory } \\ \text { IVC } & \text { independent verification contractor } \\ \text { kcpm } & \text { thousand counts per minute } \\ \mu R / h & \text { microroentgens per hour } \\ \text { LLD } & \text { lower limit of detection } \\ \text { ORNL/PAG } & \text { Oak Ridge National Laboratory/Pollutant Assessments } \\ & \text { Group } \\ \text { PIC } & \text { pressurized ionization chamber } \\ \text { SFMP } & \text { Surplus Facilities Management Program }\end{array}$


APPENDIX A

POST-REMEDIATION SURVEY BY EG\&G 


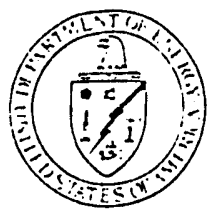

\section{Department of Energy \\ Itaho Operations Ofilice iEs DOE Fláce

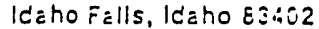

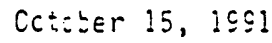

M.s. Gloria H. Stevens

Oak Ridge liational Laj

P. 0. Eox 2567

Gräid Juncticn, co $5: \vdots 02-2557$

SUBJECT: Post DEContanination and DEComissioning of the EORAX-V Turbine Building - ERio-439-9l

Dear Ms. Stevens:

Please find enclosed a copy of the fost Decontamination and Decommissioning (DSD) Survey of the EORAX-V Turbine Building. This survey is provided to assist the Independent Verification Contractor (IVC) with the preparation of a viorkplan that will outline the methodology for the verification and

certification of DSD activities at the BORAX-V Turbine suilding site located at the Idaho National Engineering laboratory.

Should you have any questions, please contact me at (FTS) 583-0193, commercial (208) 526-0193, or A. W. Mikkola at (FTS) 583-0725, commercial (203) 526-0725.

\section{Sincerely,}
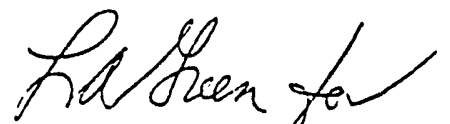

W. N. Sato, Acting Director Environmental Restoration Division

Enclosure

cc w/o enc: S. G. Stiger, EG\&G

R. H. Meservey, EGSG

G. R. Rodmen, EG\&G 
A-2

CEniser 7, 10:1

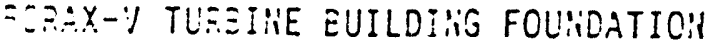

FOST CECCHTHMILATIGH RADIOLOGICAL

SLEVEY RESULTS 


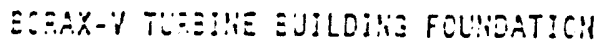

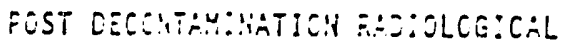

SUIEY RESLLTS

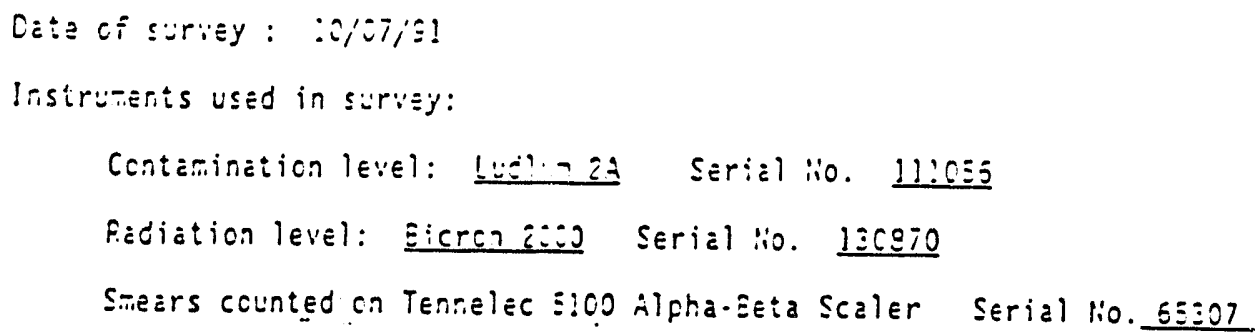

Siear Results: Ho sineabla csitamination cetected on ary of the $100 \mathrm{~cm}^{2}$ sina ars.

fio ilpha conta-ination detected on eny of the sriests.

Ceneral Notes:

All contaminaticn levels rog:rt: backegreund (bkgj.).

Eackgrourd level used at E:S:X-X-V is 100 cpan.

Ail exterior and interier isundation wiells and the riain flocr are rediologically cleen.

Easenert flocr, excludirg ito sump pit trench end suip pit, has only cre area of efproxi-aiely 1 it $^{2}$ with fixed ccritemination of meximuin 300 com Ėove beckçround (area i..erkis nith " $x$ ").

Suin pit contamination leveis averaçe 200 cpm atove backçround. 


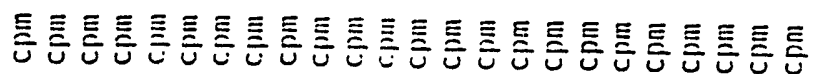

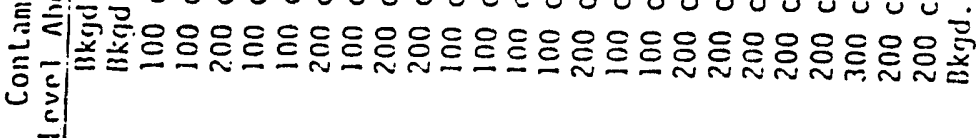

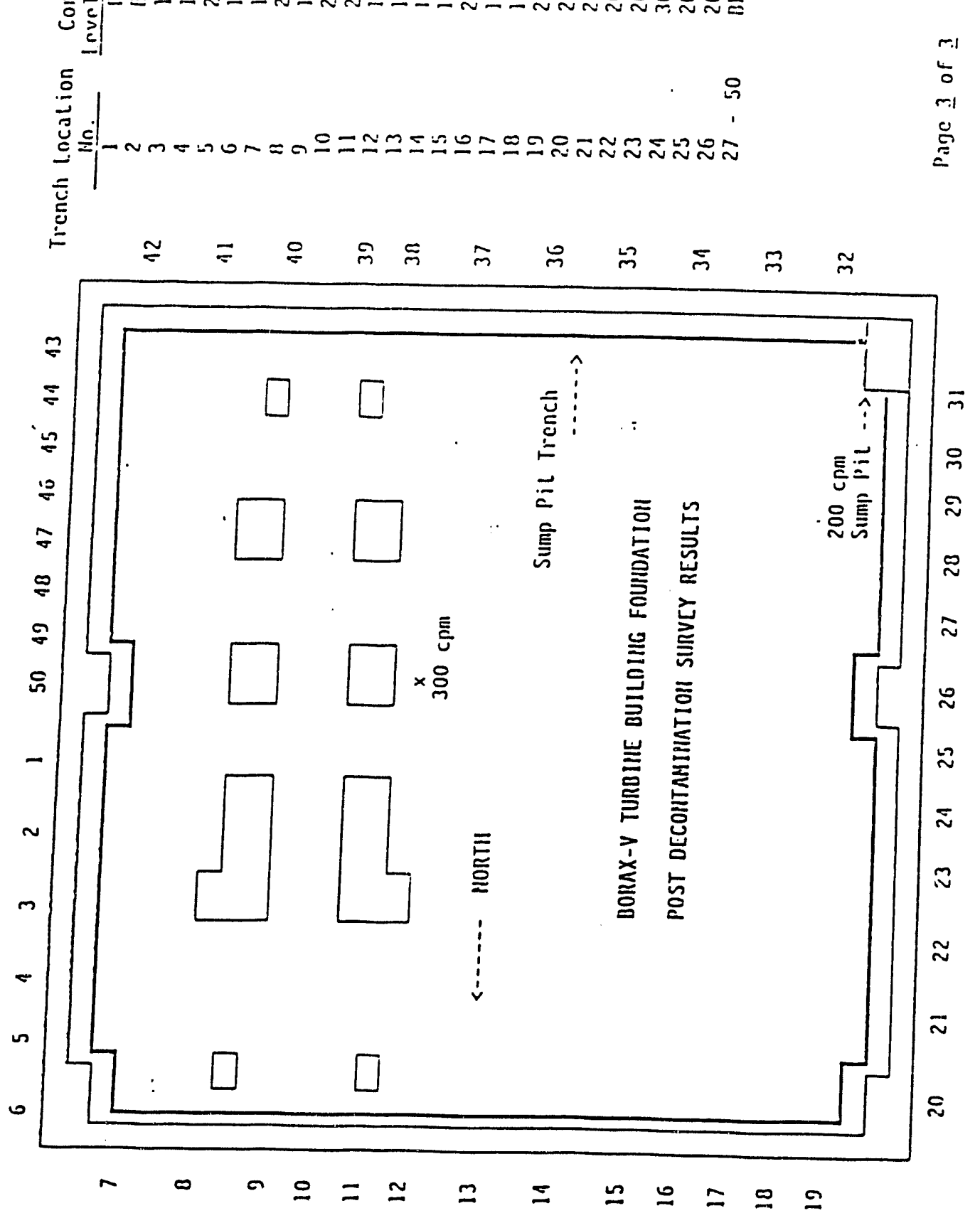




\section{Department of Energy}

$$
\begin{aligned}
& \text { Itát.o Giefáticns Cutice } \\
& \text { iEs }=C E \text { Flace } \\
& \text { leatofalis, icatog:ace } \\
& \text { :ivver:ter I, }: \leqq \leqq \text { ! }
\end{aligned}
$$

Mr. D. K. Halford

Oak Ricge Naticnal Laboratory

Grand iuriction frojec: Office

P. 0 . छox $2 E \leq 57$

Erenio iurction, co EjE02

SUEJECT: SCEAX-V CSJ REdiclogiCal Survey - ERD-474-SI

Dear Mr. Halferd:

As per your request, please find exiclosed the latest EORAX-V Turbine Euilding Redioactive Survey. The values have been converted from counts per minuta (cpm) to disintegrations per minute $p \in r 100 \mathrm{~cm}^{2},\left(d p m / 100 \mathrm{~cm}^{2}\right)$ using $C 5-137$ as the prinsery isotcpe.

he look forward to your field survay trip the first heek in liovember.

Please call A. W. Mirkola at (FTS) $\$ 83.0725$ if you have any questions.

$$
\text { Sincerely, }
$$

$$
\because 67 \frac{1}{\frac{1}{10 !}}
$$

W. N. Sato, Actirg Director Environmental Restoration Division

Enclosure

cc: G. Steveris, OFill/GJPO, w/enc.

R. H. Meservey, EG\&G, $w / 0$ enc.

G. R. Rodmen, EG\&G, $w / 0$ eric. 
A-6

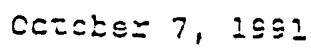

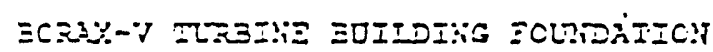

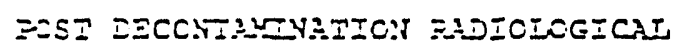

ST:VEN EESTISS 


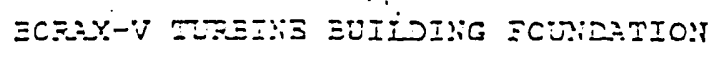

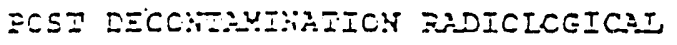

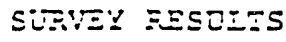

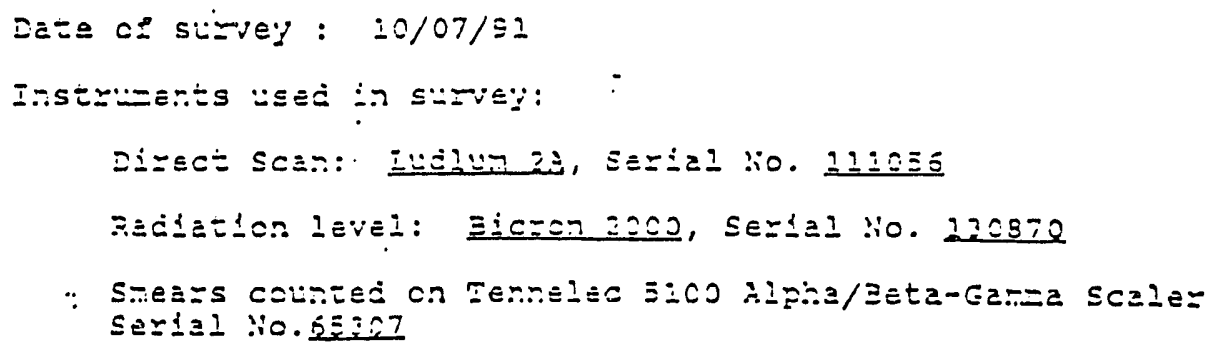

Gereral lictes:

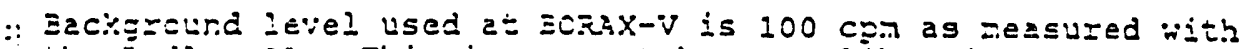

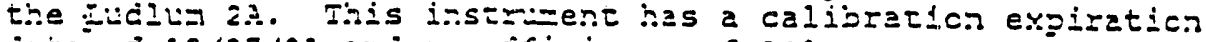

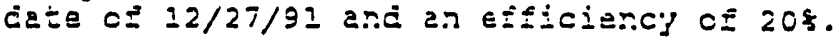

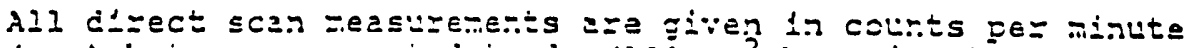

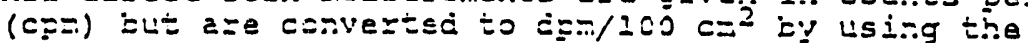

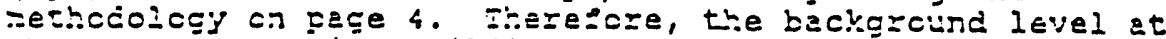

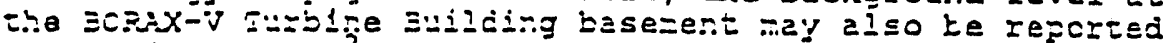
as 528 cin/200 $\mathrm{cm}^{2}$.

AlI exterlor anj intericl Ecuncatich halls have been sinfeyed ard inird to je fiee of lixed and locse cs:ra=irat1cr.

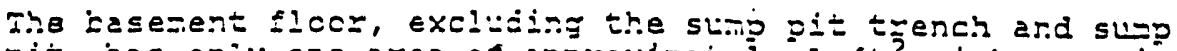

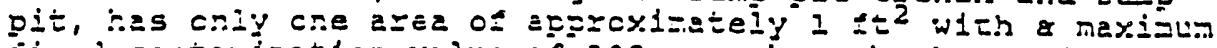

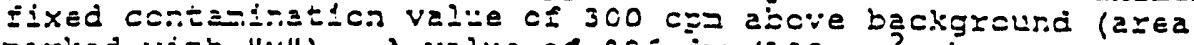

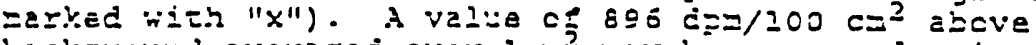

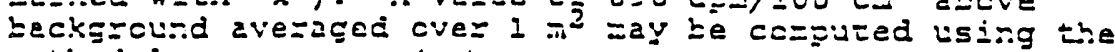
methccology c.a gage 4 .

T:e fixed çataminat1ca levels in the sunp git everage 1075 çe:=/100 cm ajcve iackgrcind.

All lixed cortanination levels are reported c. page 4 in

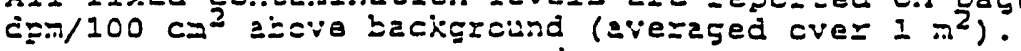


A-8

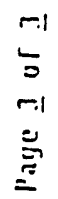

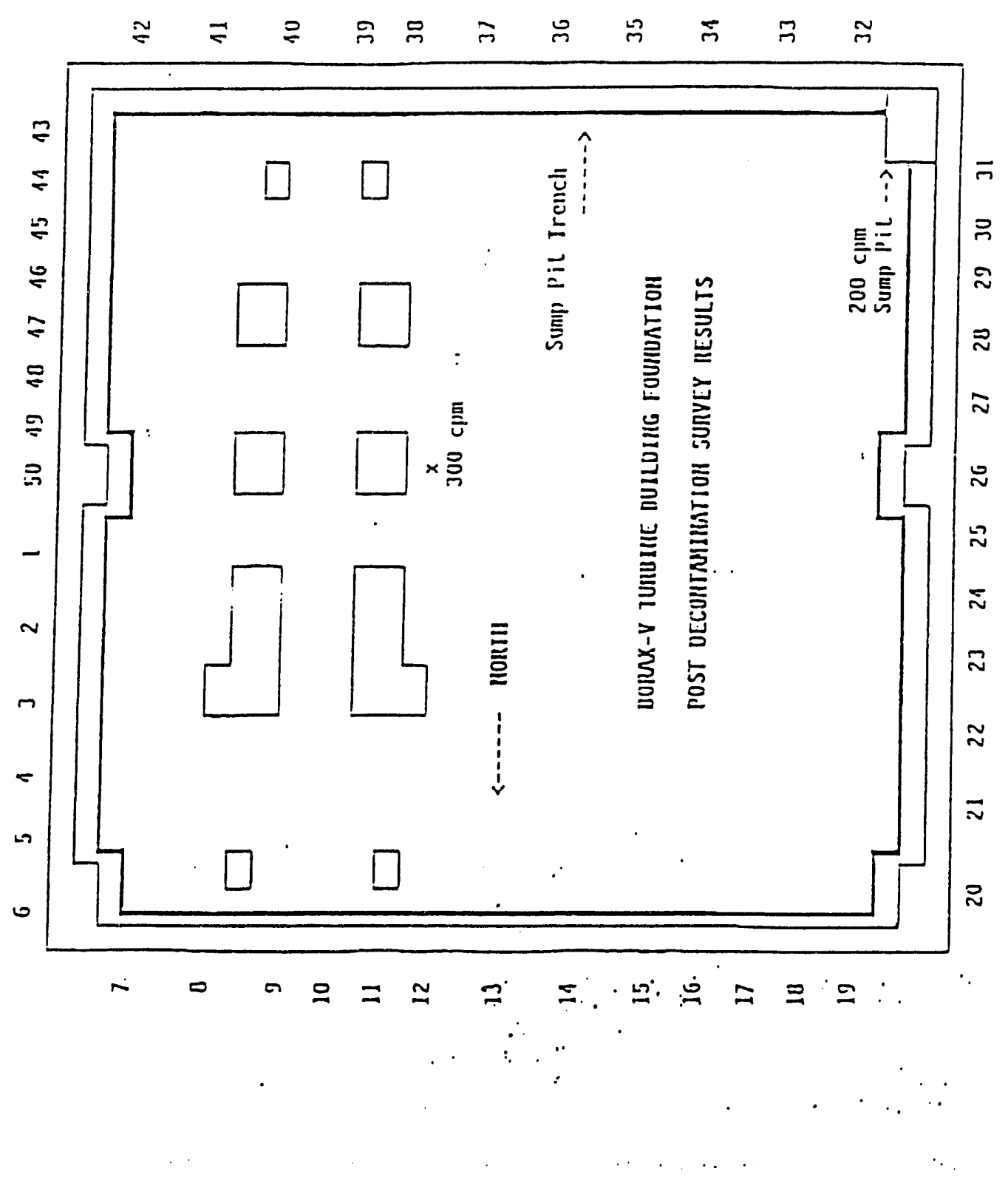




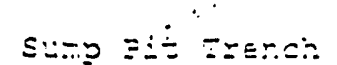

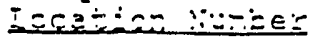

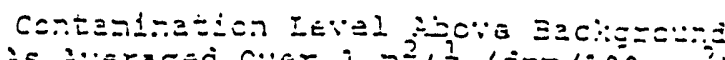

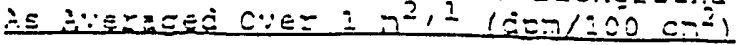

$\equiv: \Xi$.

$\equiv \therefore \Xi$.

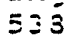

$2 \div 3$

$\therefore 075$

$\equiv 33$

$\equiv 23$

$20 \% 5$

三3

$\therefore 07.5$

$\therefore 075$

533

533

533

538

1075

इ38

$5=3$

1075

1075

2075

1075

1075

1613

1075

1075

보․

1. These velueg iere crigi-ally regcrzed in con using the

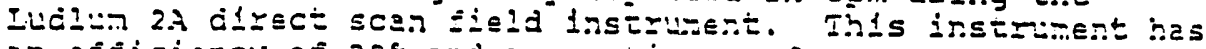
an ef:iciercy of 20 and a colnting sirizce area cI 15.5

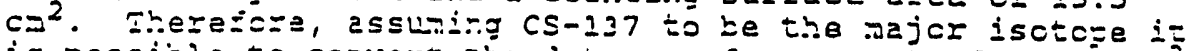

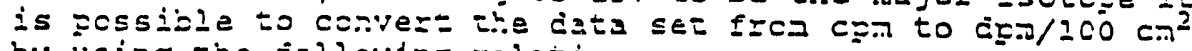
Ey using the Eclloiving Ielation:

$$
\frac{\mathrm{csin}}{15.5 \mathrm{~cm}^{2}} \times 5 \times 6.45=\frac{\dot{\varepsilon=\pi}}{100 \mathrm{~cm}^{2}}
$$

IL_ther, tie tabulated values have been avezaged cuer a $1 \mathrm{~m}^{2}$ surłace area. This is gessible by saying that a 1 =eter sGCFer: of the toerch 6 inches wide represents approximate.y 1/6th o: the $1 \geq^{2}$ azea. IhLs, the converted values are divided by 6 ard are tabulated akcve. 


\section{APPENDIX B}

\section{SURVEY AND ANALYTICAL EQUIPMENT}


B-1

APPENDIX B

\section{SURVEY AND ANALYTICAL EQUIPMENT}

The display or description of a specific product is not to be construed as an endorsement for that product or its manufacturer by the authors or their employer.

\section{DIRECT RADIATION MEASUREMENTS}

Victoreen portable ratemeter

Model 490 THYAC III

Victoreen, Cleveland, Ohio

Victoreen NaI scintillation detector

Model 489-55

Victoreen, Cleveland, Ohio

Eberline beta-gamma radiation "pancake" detector

Model HP-260

Eberline, Santa Fe, N.M.

Ludlum ratemeter-scaler

Model 2221

Ludlum, Sweetwater, Tex.

Reuter-Stokes pressurized ionization chamber

Model RSS-111

Reuter-Stokes, Twinsburg, Ohio 
Eberline alpha radiation scintillation detector

Model AC-3-7

Eberline, Santa Fe, N.M.

Bicron Analyst ratemeter-scaler

Bicron, Newbury, Ohio

Ludlum gas proportional counter floor monitor

Model 239-1F

Ludlum, Sweetwater, Tex.

\section{LABORATORY ANALYSES}

Ludlum dual alpha, beta-gamma radiation smear counter

Model 2929

Ludlum, Sweetwater, Tex.

Gamma spectroscopy

ND multichannel analyzer

Model 9900

Nuclear Data Systems $\bullet$

Canberra Industries,

Itasca, Ill.

High purity germanium lithium detectors

ORTEC $\bullet$, Tennelec,

NDo Corp,

601 Oak Ridge Turnpike

Oak Ridge, Tenn. 


\section{APPENDIX C}

DECONTAMINATION OF HOT SPOTS IDENTIFIED AT BORAX-V 


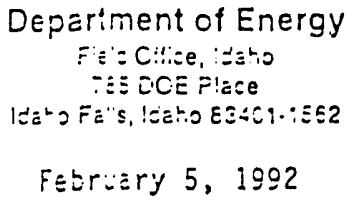

FEtruary 5, 1992

Kis. G. H. Stevens

Oak Ridge National Laboratory

P.O. Eox 2557

Grind Junction, Colerios $81502-2557$

SUBJECT: Survey of the ECFix-V Turbine Euildirg post Decontamination RPO- 21-92

Dear Mis. Stevens:

This letter formally transmits the results of efforts to remove fixed contamination from three small areas on the Turbine Building floor. These three small areas were icentified by your staff during the Independent Verification Contracior (IVC) Effort in November and December of 1991. The final readings meet ine requirements of OCE Order $\$ 400.5$.

If you have any questions regarding these results, please contact A. W. Mikkola at (FTS) 583-0725.

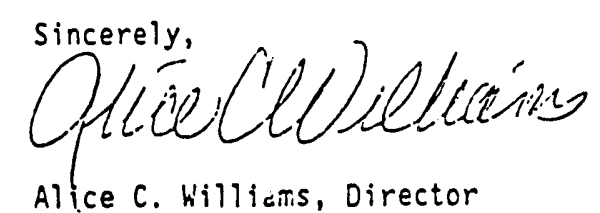

Envirorimental Restoration Division

Enclosure 


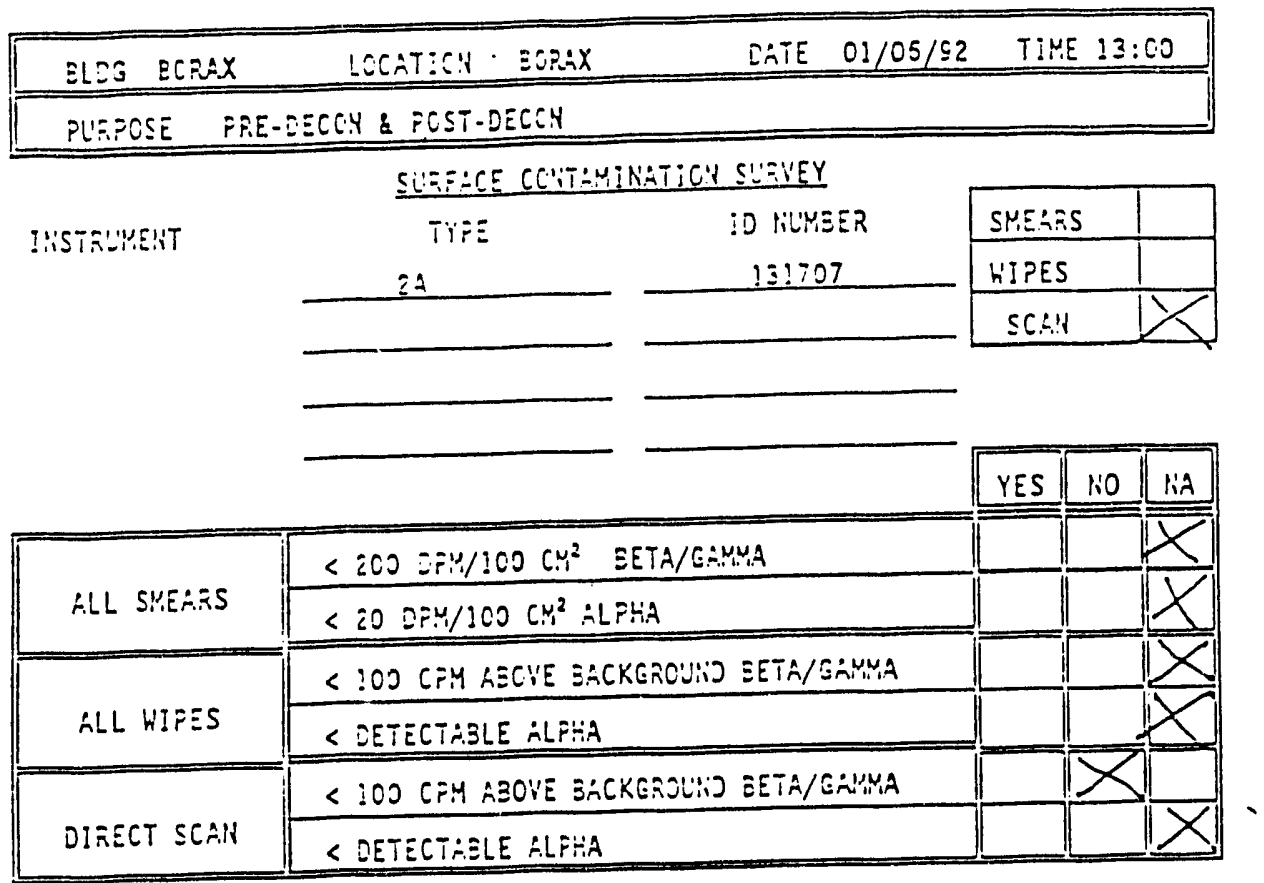

IF HO; LIST THOSE EEEATER THAN THE YALUES IHDICATED

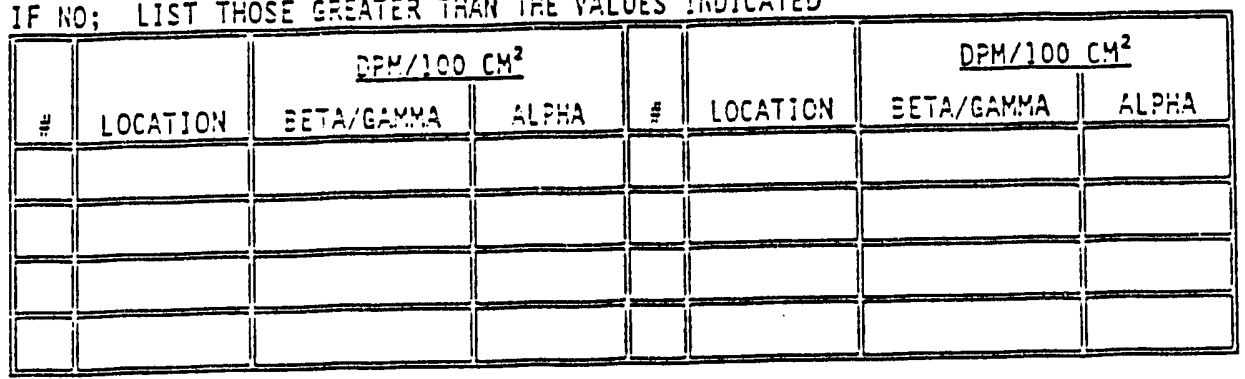

\section{ESDIATION SUEVEY}

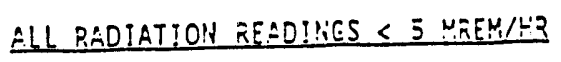

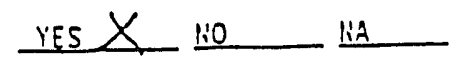

SEE $\cong L \& \cong 2$ ATTACHUELITS

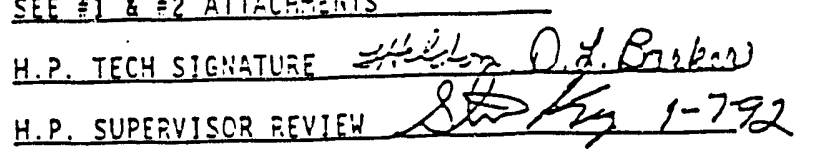

DOSE REC. MREM O 
C-3

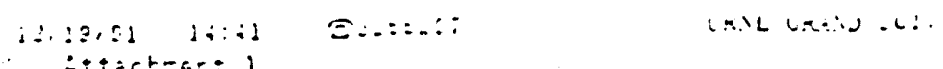

picge 1 of 3

Fie [ecen : :

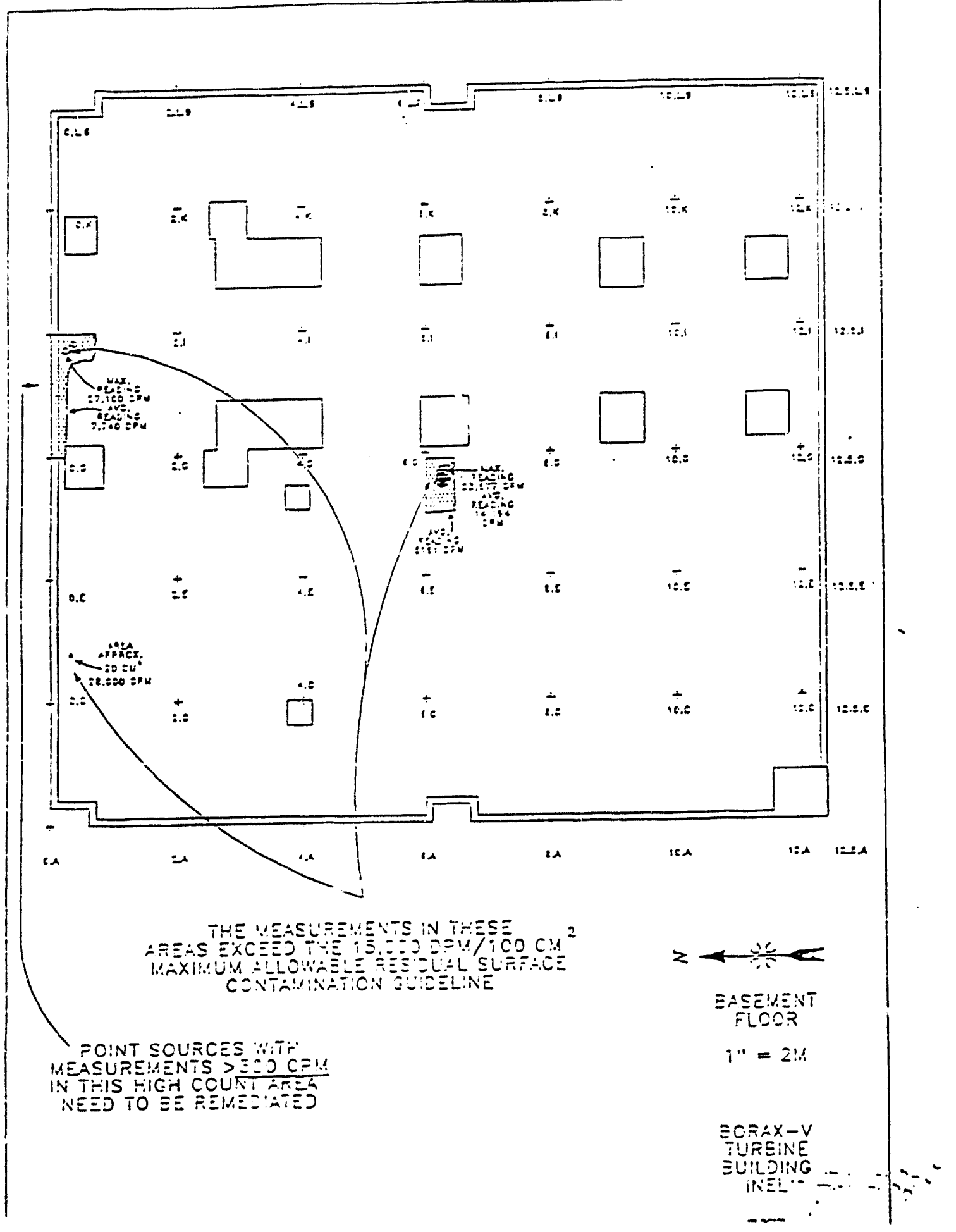


$\because 2:: 3, \vdots: \quad 1:: ; 1$

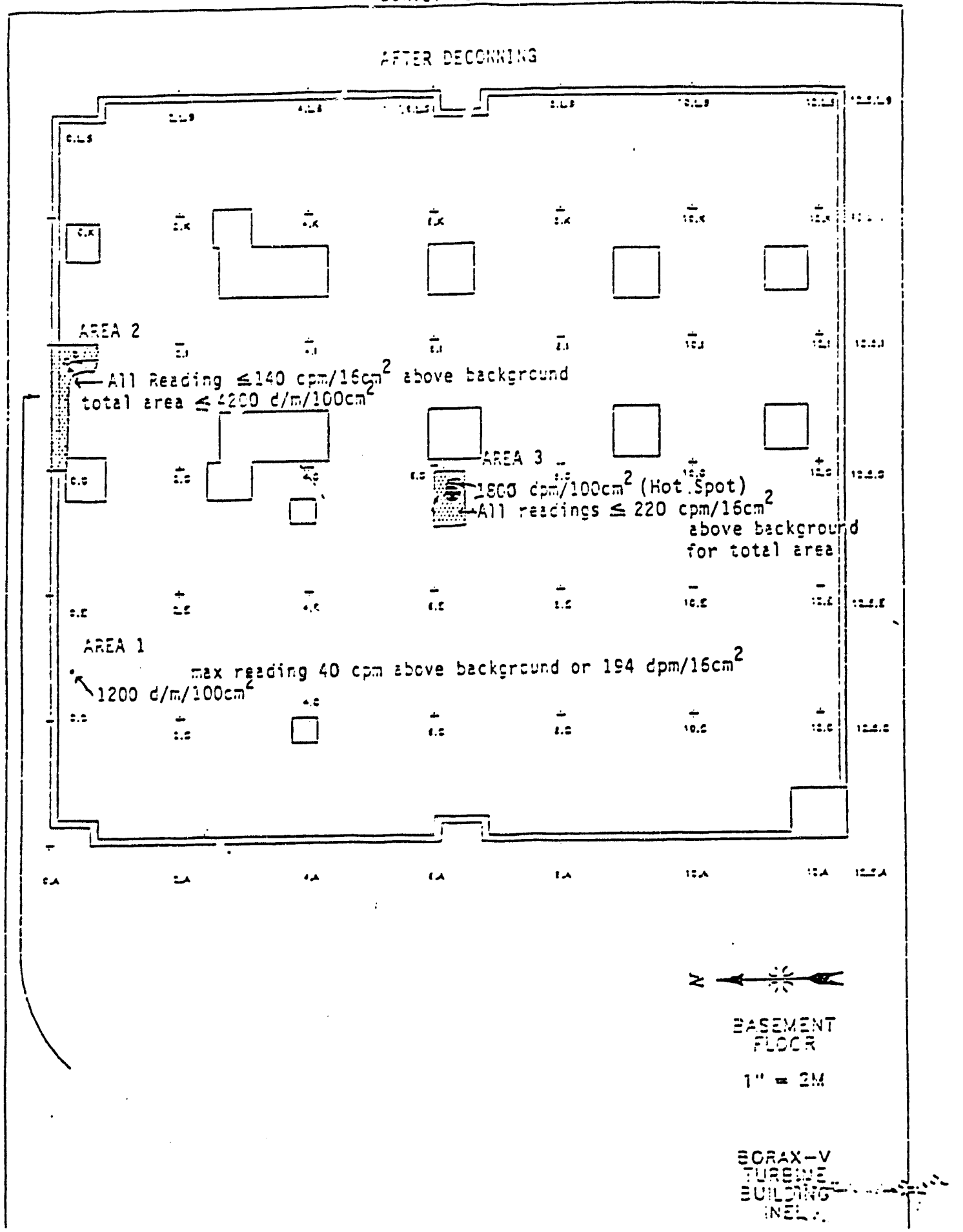




$$
\text { C-5 }
$$

Attechent 1

Page 3 of 3

$$
\text { Calculation Inicrietion }
$$

A. To figure difn

1. $\frac{\operatorname{com}-\text { tkef }}{\text { eff of instrutent }}=$ c.r.

b. To coniert $d / m / 1=\mathrm{cm}^{2}$ to $d / \pi /:: 0 \mathrm{sm}^{2}$ $d / m / 16 \mathrm{~cm}^{2} \times 6=d / m / 100 \mathrm{~cm}^{2}$

c. Instrument $231707 \mathrm{cal}$ ibration intorimaticn eif. Cs 137 20.6\%

Sr 50 2 $25 \%$

Co ED 3.2\%

ic $\subseteq 9$ 12.8\%

NOTE: The instrument used has a $13 \mathrm{~cm}^{2}$ detection area 


\section{C-6}

Attácrient 2

Pace i of 4

$\Xi:: 5:: 27$

LRYL CI:S 20 .

تே:5;

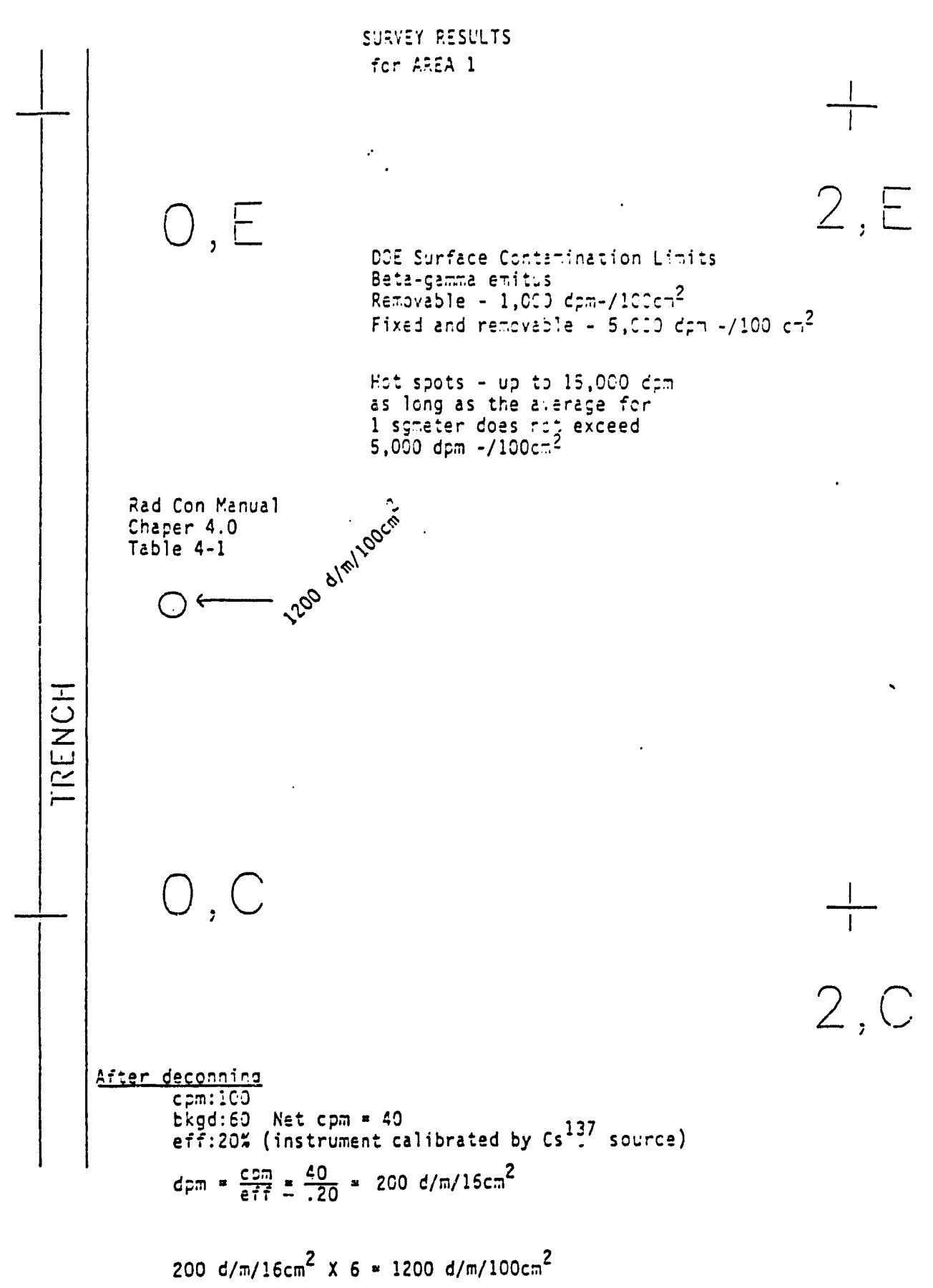

SU:VEY RESLLTS

icr FEEA 1

Renovable - 1 cej dan-110ne-?

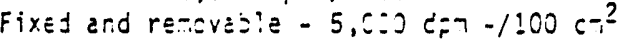

5 long as the ai irege for

sgmeter does i:

$5,000 \mathrm{dpm}-1100 \mathrm{c}^{-}-$

Rad Con M.enual

Chaper 4.0

able 4-1

$\bigcirc$

$2 ;$

Aiter deconning

cim: :C.J

ckga:6j NEt CPM $=40$

(instrument calibrated

$200 \mathrm{~d} / \mathrm{\pi} / 16 \mathrm{~cm}^{2} \times 6=1200 \mathrm{~d} / \mathrm{m} / 100 \mathrm{~cm}^{2}$ 


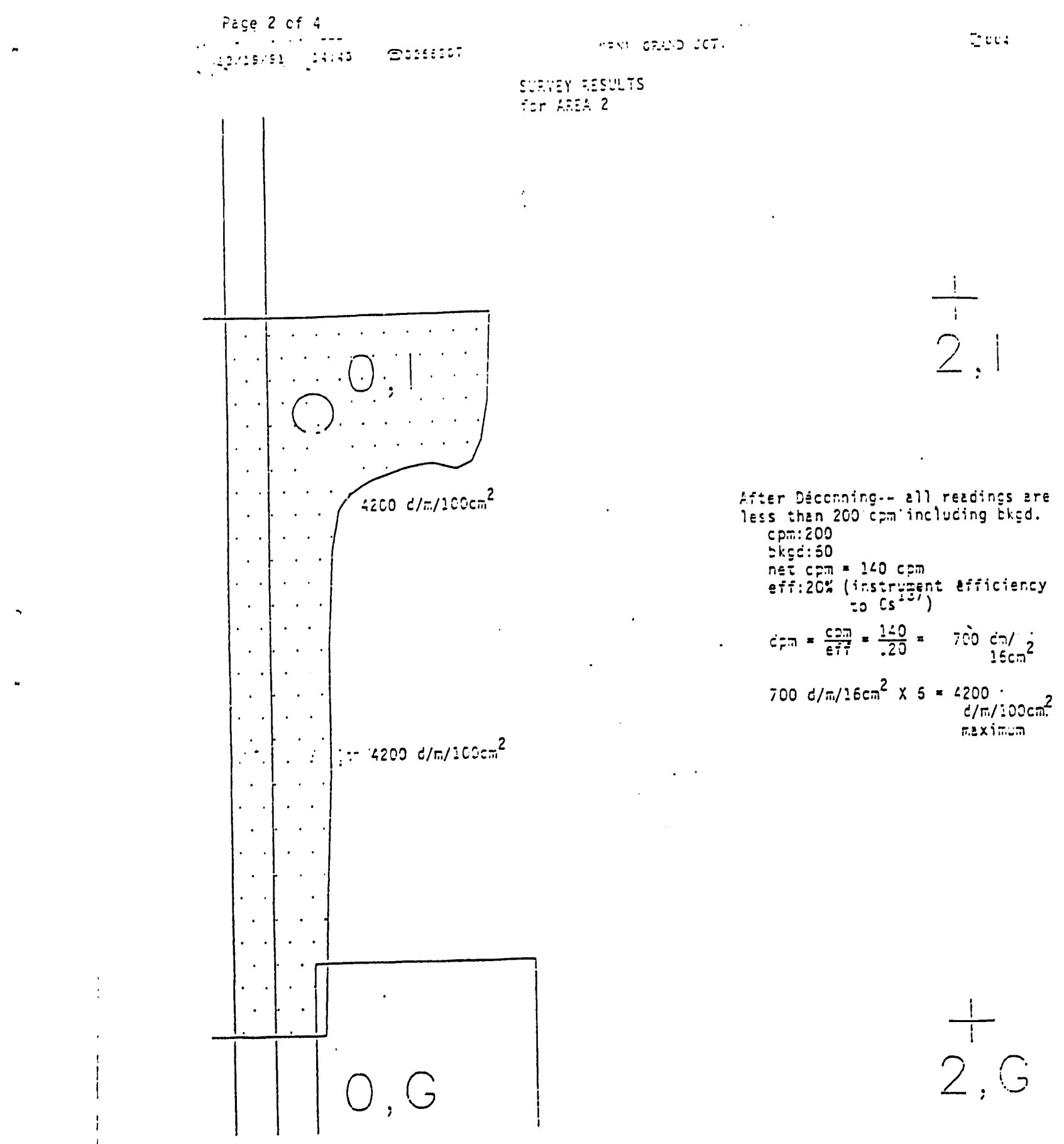




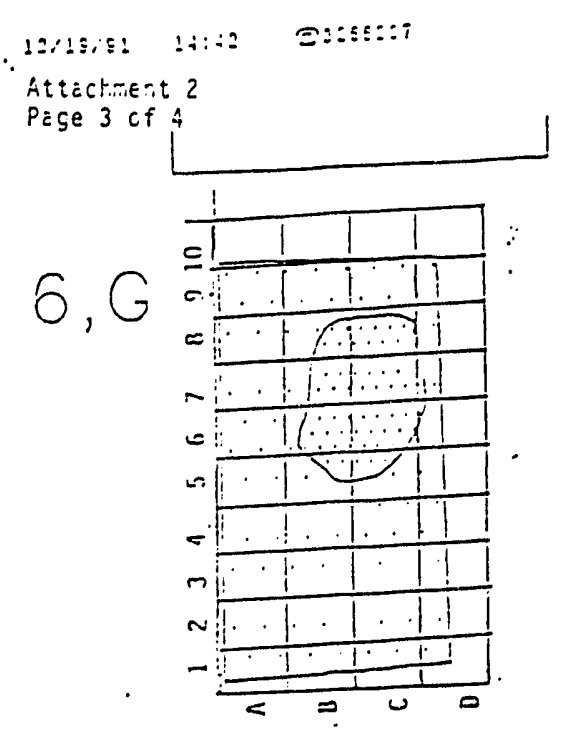

r.:Bt CR:D :65.

Cis02

ÉLYEY EESLLTS

icr rified 3

Attichtinert

+
$6, E$

$\frac{1}{1}$

8, E

$\frac{1}{1}$

8.6 


\section{RREA 3 SURYEY RESLLTS}

Pre-Decon fiveríges

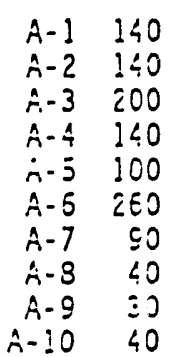

$3-1 \quad 1 \leq 0$

$3-2 \quad 220$

$3-3 \quad 2<0$

$\vdots-4 \quad \Xi \leq 0$

$3-5 \quad 3 \div 0$

$3-5$ ¿ह०

$\Xi-7 \quad 200$

¿-8 60

$3-2 \quad 40$

$8-10 \quad 40$

$\begin{array}{rr}C-1 & 100 \\ C-2 & 170 \\ C-3 & \vdots 20 \\ C-4 & 220 \\ C-5 & 5 \equiv 0 \\ C-6 & 500 \\ C-7 & 2 \leq 0 \\ C-3 & 1=0 \\ C-9 & 40 \\ C-10 & 40\end{array}$

$D-1 \leq 0$

$0.2 \quad 70$

$0-3 \quad 220$

$0-4 \quad 2 \leq 0$

D-5 $2 E 0$

$2.5 \quad 2 \div 0$

$\begin{array}{ll}0.7 & 50\end{array}$

$0-8 \subseteq 0$

These readings are in crim/lecm above tackground.

POST-DECON SURYEY RESULTS

Post-Decon on $A, B, C, \& D \cong$ : $3-7$

All averages $40-60$ cpm above background

The rieximum count rate in the hot spot within the area identified is $60 \mathrm{cpm}$

$c_{\mathrm{Fm}}=\frac{\mathrm{com}}{\mathrm{eff}} \mathrm{dpm}=\frac{60 \mathrm{csm}}{.20}=300 \mathrm{ipm} / 16 \mathrm{~cm}^{2}$

$300 \mathrm{dpm} \times 6=1800 \mathrm{dp} / 100 \mathrm{~cm}^{2}$ mexinum within the area identified 
APPENDIX D

$\mid$ 
D-1

\section{APPENDIX D \\ STATEMENT OF VERIFICATION FOR BORAX-V TURBINE BUILDING AT IDAHO NATIONAL ENGINEERING LABORATORY, IDAHO FALLS, IDAHO}

An independent assessment of remedial action activities at the Borax-V turbine building at Idaho National Engineering Laboratory, Idaho Fall, Idaho, has been accomplished by the Oak Ridge National Laboratory (ORNL) Pollutant Assessments Group. The purpose of the assessment was to confirm the site's compliance with applicable Department of Energy (DOE) guidelines. The assessment included reviews of the Decontamination and Decommissioning Plan and data provided in the pre- and post-remedial action surveys. In addition, an independent verification survey of the facility was conducted November 20-27 and December 9-15, 1991.

The independent verification survey included alpha, beta-gamma, and gamma radiation scans, smears for removable contamination, and direct measurements for alpha and beta-gamma radiation activity on the basement and mezzanine floors and the building's interior and exterior walls. In addition, soil samples were taken, and alpha, beta-gamma, and gamma radiation exposure rate measurements were performed adjacent to the building.

Based on the findings of this survey, the measurements on the building surfaces at this facility were within the established contamination guidelines except for elevated beta-gamma radiation levels on three floor surface areas. These areas were subsequently remediated by the remedial action contractor (RAC). ORNL reviewed the RAC's report following this remediation and agrees that the remediation was effective in removing the source of the elevated direct radiation. The independent soil analyses indicated no ${ }^{60} \mathrm{Co}$ above detection limits. The highest ${ }^{137} \mathrm{Cs}$ analysis result was $4.6 \mathrm{pCi} / \mathrm{g}$; this value is below the site-specific guideline of $10 \mathrm{pCi} / \mathrm{g}$ for ${ }^{137} \mathrm{Cs}$. 


\section{D-2}

Based on the data in the post-remedial action report and the independent verification survey results, the radiologic condition of the Borax- $\mathrm{V}$ turbine building conforms to the guidelines outlined in the Verification and Certification Protocol for the Formerly Utilized Sites and the Surplus Facilities Management Programs, Office of Environmental Restoration, U.S. Department of Energy, Washington, D.C. 
ORNL/TM-12362

\section{INTERNAL DISTRIBUTION}
1. B. A. Berven
2. R. L. Coleman
3. W. D. Cottrell
4. D. K. Halford
5. M. K. Jensen
6 - 11. C. A. Little
12. P. T. Owen
13. G. A. Pierce
$14-16$.
17.
18.
19. Central Research Library
20 - 21. Laboratory Records
22. Laboratory Records - RC
23. ORNL Patent Section- RC
24. ORNL Technical Library, Y-12

\section{EXTERNAL DISTRIBUTION}

25. P. V. Egidi, Oak Ridge Institute of Science and Education, P.O. Box 2567, Grand Junction, CO 81502

26. S. K. Mather, Oak Ridge Institute of Science and Education, P.O. Box 2567, Grand Junction, CO 81502

27. Office of Assistant Manager, Energy Research and Development, Oak Ridge Operations Office, P.O. Box 2001, Oak Ridge, TN 37831-8600

28 - 29. Office of Scientific and Technical Information, U.S. Department of Energy, P.O. Box 62, Oak Ridge, TN 37831 

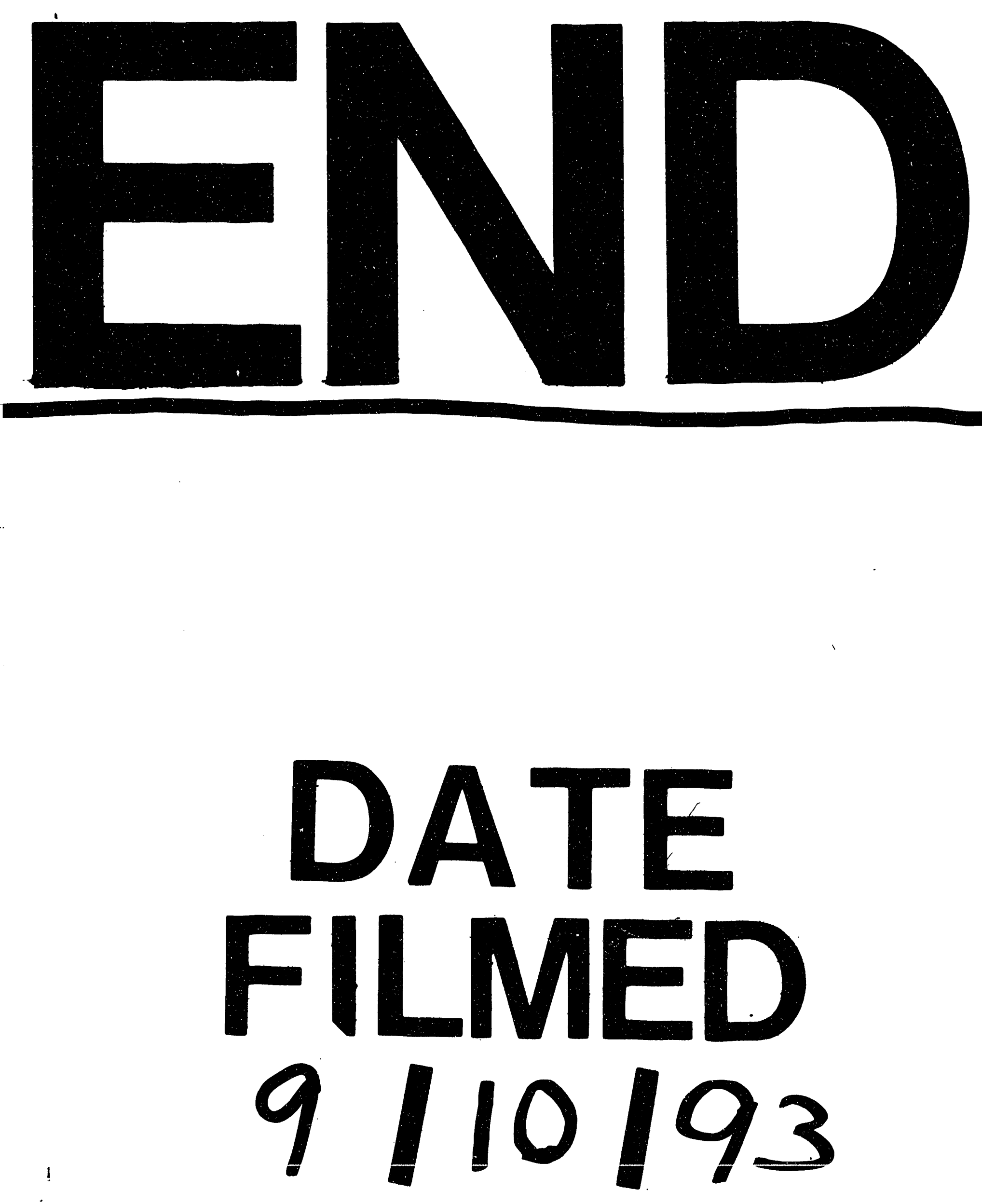
